\title{
The genus Cycas (Cycadaceae) in Indonesia
}

\author{
A.J. Lindstrom ${ }^{1}$, K.D. Hill ${ }^{2}$ and L.C. Stanberg ${ }^{2}$ \\ ${ }^{1}$ Nong Nooch Tropical Botanical Garden, Sattahip, Chonburi 20250, Thailand \\ ${ }^{2}$ National Herbarium of New South Wales, Royal Botanic Gardens, Mrs Macquaries Road, Sydney \\ 2000, Australia
}

\begin{abstract}
The genus Cycas is reviewed for Indonesia. Ten species are enumerated, two of them new (C. sundaica, C. montana). Lectotypes are designated for Cycas Subsection Endemicae, C. glauca, C. circinalis subsp. riuminiana var. curranii forma maritima J.Schust. The species are placed within an infrageneric classification previously outlined. Distribution of all taxa is mapped, and a key to species provided. Extensions into Malaysia (C. edentata) and Papua New Guinea (C. apoa, C. papuana, C. scratchleyana) are discussed under the species. Previous recordings of C. circinalis from Indonesia are discussed.
\end{abstract}

\section{Introduction}

The genus Cycas is the single constituent genus of the family Cycadaceae, itself the basal lineage of the living cycads or Cycadophyta (Stevenson 1992). It is also the sole living cycad group occurring in Asia. The only known fossil evidence for this genus is from the Eocene of China and Japan, and this, together with the occurrence of all major lineages in the genus in mainland Asia, supports a long-term presence and probable origin of this genus in that region (Hill 1995b). Cycas consists of about 100 species, chiefly IndoChinese (about 40 species) and Australian (27 species). The genus also occurs in the Malesian region, Japan and India, extending to Micronesia and Polynesia, Madagascar and East Africa. Plants are commonly understorey shrubs in forest, woodland or savanna habitats. Ten species are known in Indonesia.

The cycad flora of Indonesia is relatively sparse in comparison to Indochina and northern Australia, both of which show extensive local radiations. A similar but smaller radiation, however, appears to have occurred in the Sunda region (Nusa Tenggara) of Indonesia.

Examination of existing herbarium material of the genus Cycas L. from Indonesia shows that most specimens are sterile, often incomplete and often hard to assign to any described taxon or even subsection of the genus. This has contributed to the taxonomic confusion, with a number of valid taxa being put into synonymy with unrelated taxa, based upon examination of sterile specimens and inaccurate illustrations. This also highlights the necessity of field studies in this group. 
The present work is the outcome of our separate and combined studies, with a total of three field trips during the period 1999-2000. Herbarium collections held by A, B, BM, BO, E, G, K, L, LAE, NY, P and SING have been examined by at least one author. Terminology is as in previous papers in this series (e.g. Hill 1994a), as are generic and specific concepts applied. Conventions in measurements taken and presented in the following descriptions are as in other papers in this series, and are set out in Lindstrom and Hill (2007). Many of the measurements were made on fresh material; in a few instances these measurements are not given in the descriptions because they were not recorded or fertile material was absent in the field.

\section{Taxonomic history}

The genus Cycas was first recorded from Indonesia by Rumphius (G.E. Rumpf), with his description of "Olus Calappoides" (1741). The Rumphius plates were then cited by Linnaeus (1753) in his description of C. circinalis L., a species in India.

The existence of a distinct Indonesian taxon was first recognised by Roxburgh (1832: 747), who mistakenly applied the name C. sphaerica Roxb. to plants from India belonging to the $C$. circinalis alliance (Lindstrom \& Hill 2007). The distinct Indonesian taxon he then treated under the name C. circinalis.

This Indonesian species was first legitimately recognised by Miquel (1839: 45) as C. rumphii Miq., although Miquel was never clear on the specific limits of this taxon. He also described C. celebica Miq. (1839: 45), C. rumphii var. timorensis Miq. (1841: 125) and C. circinalis var. javana Miq. (1842: 28) but later abandoned all of these (see below). The outcome of Miquel's confusion was a reluctance by many other authors to recognise C. rumphii at all, and the name $C$. circinalis has been widely applied to material belonging to the C. rumphii alliance up to the present day.

The comprehensive account of the genus by de Candolle (1868) recorded C. circinalis var. javana, C. rumphii and the variety C. rumphii var. timorensis from Indonesia, and listed C. celebica as a species without distinguishing characters. De Candolle had, however, largely followed Miquel's 1851 treatment in developing his account.

Warburg (1900) recognised the presence of a coastal taxon in New Guinea, assigning it to C. rumphii. This coastal taxon has also been assigned to C. circinalis (White 1923). Koorders (1911) at first used only the name C. circinalis, although he later (1913) took up the name C. rumphii. Duyster (1927) also used only the name C. circinalis. Backer (1925) placed most Javanese material under C. rumphii, and Pilger (1926) subsumed all of the Indonesian taxa under C. rumphii with no further comment. Ochse (1931) also regarded all Javanese material as Cycas rumphii.

Schuster (1932) clearly showed a lack of understanding of most species. He included material of the C. rumphii complex in both C. rumphii and C. circinalis (and in a number of the subspecies and varieties he erected in this species), but also included a range of other sometimes unrelated taxa in his treatments of these two species.

Backer and Bakhuizen van den Brink (1963) recorded only C. rumphii from Java.

De Laubenfels and Adema (1998) divided the Indonesian occurrences of the C. rumphii complex into C. rumphii, C. celebica and C. edentata de Laub., and applied the names C. silvestris K.D.Hill, C. scratchleyana F.Muell., C. javana (Miq.) de Laub. and C. riuminiana Porte ex Regel to material that included some of the C. rumphii complex and also the inland forest species. None of these names were wholly correctly applied (see below). 


\section{Conservation}

Populations of many Asian species appear to have declined, sometimes dramatically, over the past century. However, there is no comparative data to support this impression, and evidence for the decline is largely anecdotal and circumstantial. Several causes for a decline can be observed in action today, however, even though quantitative data on the effects are not available. Two principal threats to cycads exist in Indonesia at present, habitat loss and selective removal of plants from the wild for trade or utilisation. Some, but not all species occur in reserved areas already proclaimed, but enforcement within these areas is sometimes difficult. There is, however, a growing interest in habitat and species conservation within Indonesia, and additional reserved areas are being evaluated and declared.

The notorious Asian cycad scale insect Aulacaspis yasumatsui, has been introduced to Timor and is already widespread on Java and Bali. However the wasp that is predatory on the scale seems to be absent from these islands. A similar scenario has occurred in wild cycad populations in Guam and Taiwan (IUCN Cycad Specialist Group 2006) as well as in the U.S.A where the scale is rapidly killing many cultivated cycads (Howard et al. 1999). There is evidence that this pest was introduced many years ago as the once extensive Cycas collection in Bogor Botanic Garden, Java, was completely wiped out long ago. The scale is established in West Timor but as yet no scale has been found outside the capital Koupang.

One Indonesian species only (C. celebica) was listed in the now out-of-date (for this region) IUCN 1997 Red Book of Threatened Plants (Walter \& Gillet 1998). This has now been shown to be conspecific with C. rumphii (see below), and is not regarded as seriously threatened. Species treated below are allocated provisional conservation status codes under the new coding system devised by the IUCN (Criteria Version 3.1: IUCN 2001). Conservation status of all species is summarised in Table 1.

\section{Taxonomic treatment}

Cycas L., Sp. Pl.: 1188 (1753).

Type: C. circinalis L.; lectotype designated by Stevenson in Jarvis et al. (1993).

Dioecious palm-like shrubs with aerial or subterranean, pachycaul, cylindrical stems clad with persistent frond-bases. Fronds loosely pubescent when young, pinnate, spirally arranged, produced in seasonal growth flushes interspersed with cataphylls, lower pinnae often reduced to spines. Longitudinal ptyxis erect or rarely reflexed, horizontal ptyxis circinate. Pinnae with a single thick midrib and no lateral veins; stomata confined to abaxial surface in most species; individual ptyxis involute. Trichomes transparent, branched or simple. Leaves with vascular traces girdling stems, girdling traces not present in cataphylls or megasporophlls. Microsporophylls aggregated into determinate cones and bearing numerous microsporangia (pollen-sacs) on abaxial surfaces, with a simple sterile apex, which is often produced into an upturned spine; microsporangia opening by slits; pollen cymbiform, monosulcate. Megasporophylls spirally arranged in an indeterminate terminal rosette with the central axis continuing vegetative growth. Ovules two to many (rarely one), marginally inserted on the stipe and directed obliquely outwards (ascending); sporophyll apically dilated into a pinnatifid, pectinate, toothed or entire lamina. Seeds with a yellow, orange or brown fleshy outer sarcotesta, 


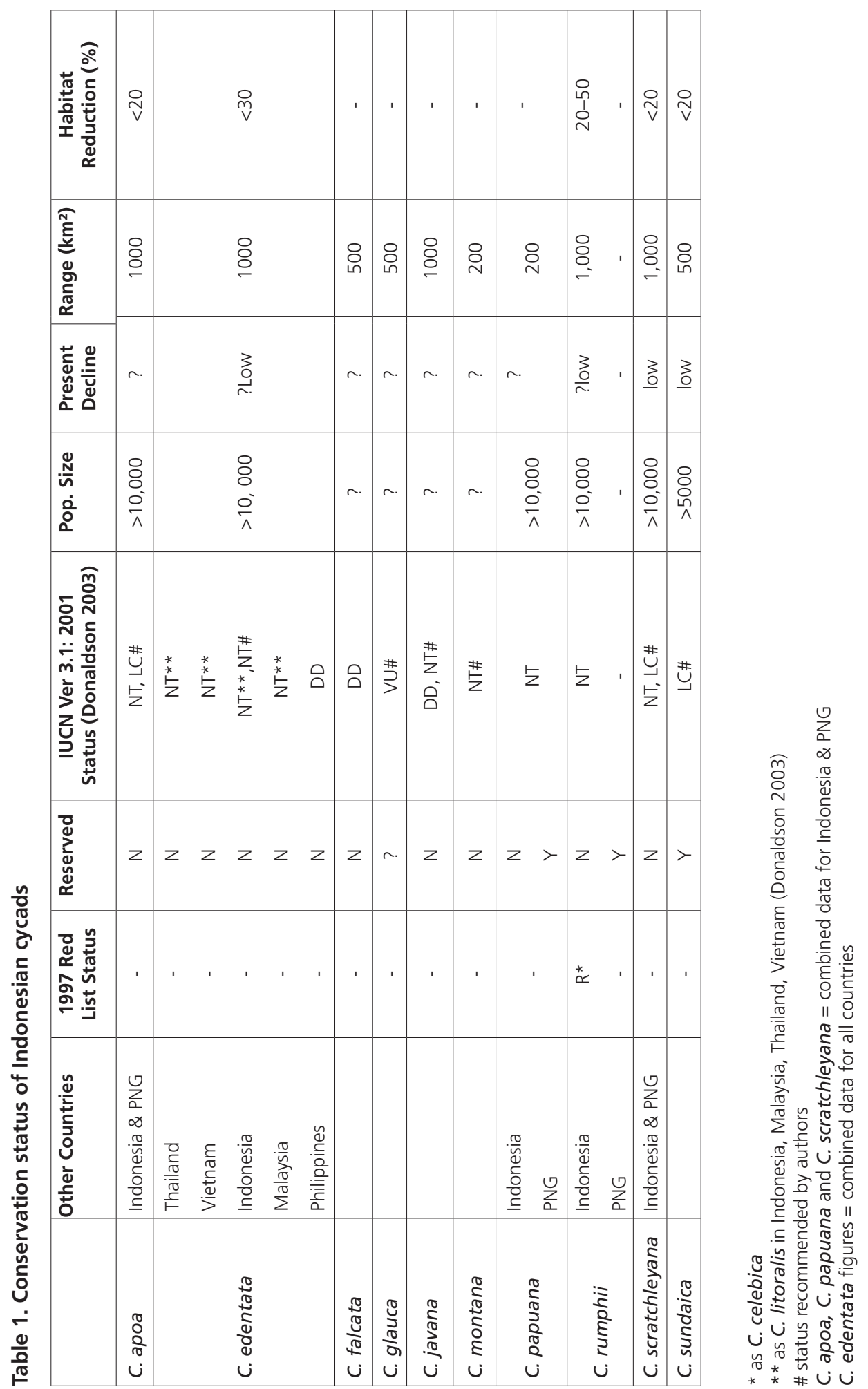


and with or without spongy tissue beneath the inner woody sclerotesta. Endosperm haploid, derived from the female gametophyte. Embryo straight; with 2 cotyledons that are usually united at the tips and a very long, spirally twisted suspensor; seeds platyspermic; germination cryptocotylar.

Six sections are now recognised: four in Hill (1995b), one additional in Hill (2008) and another one in Lindstrom et al.(2008). There has been disagreement on subgeneric division (Wang 1996, de Laubenfels 1998) and, in the light of improved understanding of the genus, none of the proposed systems would appear entirely adequate (Hill 1998, $2004 a, b)$. Two sections occur in Indonesia. One section is represented by species that occur naturally in Indonesia and a second is represented by one widely cultivated species.

\section{Key to sections}

1 Ovules tomentose Section Asiorientales ${ }^{\#}$ (C. revoluta Thunb.)

$1^{\star}$ Ovules glabrous Section Cycas

\section{Key to the species}

1 Seeds with a spongy layer inside the sclerotesta. [Subsection Rumphiae]

2 Megasporophyll with distinct lateral spines

3 Leaves openly keeled (opposing leaflets at c. $150^{\circ}$ ) 5. C. falcata

$3^{\star}$ Leaves flat (opposing leaflets at c. $180^{\circ}$ ) 8. C. sundaica

$2^{\star}$ Megasporophyll lacking distinct lateral spines

4 Seeds crested; microsporophylls short-spined 6. C. rumphii $4^{\star}$ Seeds not crested; microsporophylls long-spined 7. C. edentata

$1^{\star}$ Seeds lacking a spongy layer

5 Leaves glaucous [Subsection Endemicae] 9. C. glauca $5^{\star}$ Leaves green, not glaucous

6 Petiole spinescent; leaflets with margins slightly recurved; new shoots not bluish [Subsection Cycas]

7 Lateral spines on megasporophyll lamina obscure or absent 1. C. apoa

$7^{\star}$ Lateral spines on megasporophyll lamina present, distinct

8 Megasporophyll lamina narrow (less than $35 \mathrm{~mm}$ wide)

9 Leaflets broad (> $10 \mathrm{~mm}$ wide) 3. C. javana $9 *$ Leaflets narrow $(<10 \mathrm{~mm}$ wide) 4. C. montana

$8^{\star}$ Megasporophyll lamina broad (more than $35 \mathrm{~mm}$ wide) 2. C. scratchleyana

$6^{*}$ Petiole smooth, not spinescent; leaflets with margins flat; new shoots bluish [Subsection Endemicae] 10. C. papuana

\#widely cultivated in Indonesia, not discussed further in this treatment. 


\section{Cycas section Cycas}

Section Lemuricae Schuster, Pflanzenr. 99: 65 (1932), nom. illegit.

Section Cycas is defined by the combination of glabrous ovules, a non-pectinate megasporophyll lamina and hard \& woody mature male cones. Three subsections are recognised, circumscription following Hill (1995b), with all occurring in Indonesia. The full range of the section is from India and southern Indochina south to Australia, and from East Africa east to Tonga.

\section{Key to the subsections}

1 Seeds with a spongy layer inside the sclerotesta Subsection Rumphiae

$1^{\star}$ Seeds lacking a spongy layer

2 Sarcotesta of seed with fibrous layer present (Indonesian species) Subsection Cycas

$2 \star$ Sarcotesta lacking a fibrous layer. Subsection Endemicae

\section{Cycas subsection Cycas}

This subsection of about 12 species is defined by the absence of a spongy endotesta, the presence of fibres in the sarcotesta, and the narrow megasporophyll lamina. Seeds have not been seen in Cycas javana and C. montana, but they fit this section in other ways (leaf and megasporophyll characters), and are assumed to possess the fibrous sclerotesta of the group. The group (subsection) ranges from India and Sri Lanka to Luzon, and south and east to New Guinea. Most representatives are plants of closed forests, usually on ridges away from the coast. Four species occur in Indonesia (Fig. 1).

\section{Cycas apoa K.D.Hill, Austral. Syst. Bot. 7(6): 553-554 (1994).}

Type: Indonesia, Papua, Babrongko, S. coast of Lake Sentani, G. Iwanggin BW 5245, 4 Apr 1957 (holo CANB; iso A, BRI, LAE, L).

Literature: de Laubenfels and Adema (1998 as C. scratchleyana)

Illustration: Hill (1994a, fig. 9).

Etymology: a rendering of the local vernacular name for this taxon in the Kaka language, as spoken around the Sepik estuary in north-western New Guinea. It is pronounced AP-wah, with the first syllable stressed but short, as in 'cap'.

Vernacular: handambo (Sentani language), apoa (Kaka language, Kasmin village) (Hill 1994a).

Stems arborescent, to $2.5 \mathrm{~m}$ tall. Leaves bright green, highly glossy, 180-250 cm long, flat (not keeled) in section (opposing pinnae inserted at $180^{\circ}$ on rachis), densely and loosely tomentose with white and orange trichomes shedding as leaf expands; terminated by a spine or paired leaflets to $4 \mathrm{~mm}$ long; petiole $35-60 \mathrm{~cm}$ long, glabrous, spinescent for $80-100 \%$ of length; basal leaflets not gradually reducing to spines, $140 \mathrm{~mm}$ long. Median leaflets simple, strongly discolorous, 220-320 mm long, 11-15 mm wide, inserted at $70-80^{\circ}$ to rachis, decurrent for $7 \mathrm{~mm}$, narrowed to $2.5 \mathrm{~mm}$ at base (to $20 \%$ of maximum width), $13 \mathrm{~mm}$ apart on rachis; section flat; margins slightly recurved, often undulate; apex softly acuminate, not spinescent; midrib 
raised above, raised below. Cataphylls linear, soft, pilose. Pollen cones narrowly ovoid, orange; microsporophyll lamina firm, not dorsiventrally thickened, apical spine not prominent, upturned. Megasporophylls 20-26 cm long, orange and grey tomemtum; ovules 2-8, glabrous; lamina lanceolate, c. $35 \mathrm{~mm}$ long, c. $16 \mathrm{~mm}$ wide, lateral spines not developed, apical spine 15-30 mm long. Seeds flattened-ovoid, 45-50 mm long, $40 \mathrm{~mm}$ wide; sarcotesta orange-brown, not pruinose, 3-5 mm thick; fibrous layer present; sclerotesta smooth; spongy endotesta absent. Fig. 2.

Historical notes: included in C. scratchleyana by de Laubenfels and Adema (1998).

Distinguishing features: Cycas apoa is distinguished by the thin leaflets with narrow bases and no laminar hypodermis, continuous adaxial and abaxial hypodermis and strongly undulate margins, and the small megasporophyll lamina with reduced or no lateral spines (Fig. 2). Cycas scratchleyana from the southern side of New Guinea shares the thin, undulate leaflets, but has a much larger and relatively broader megasporophyll apex with numerous clearly defined lateral spines. The two also share continuous adaxial mesophyll and sometimes continuous abaxial mesophyll. The midrib is also narrow and usually sharply raised in both taxa. This is the species sometimes referred to as C. circinalis in northern coastal New Guinea (Borrell 1989).

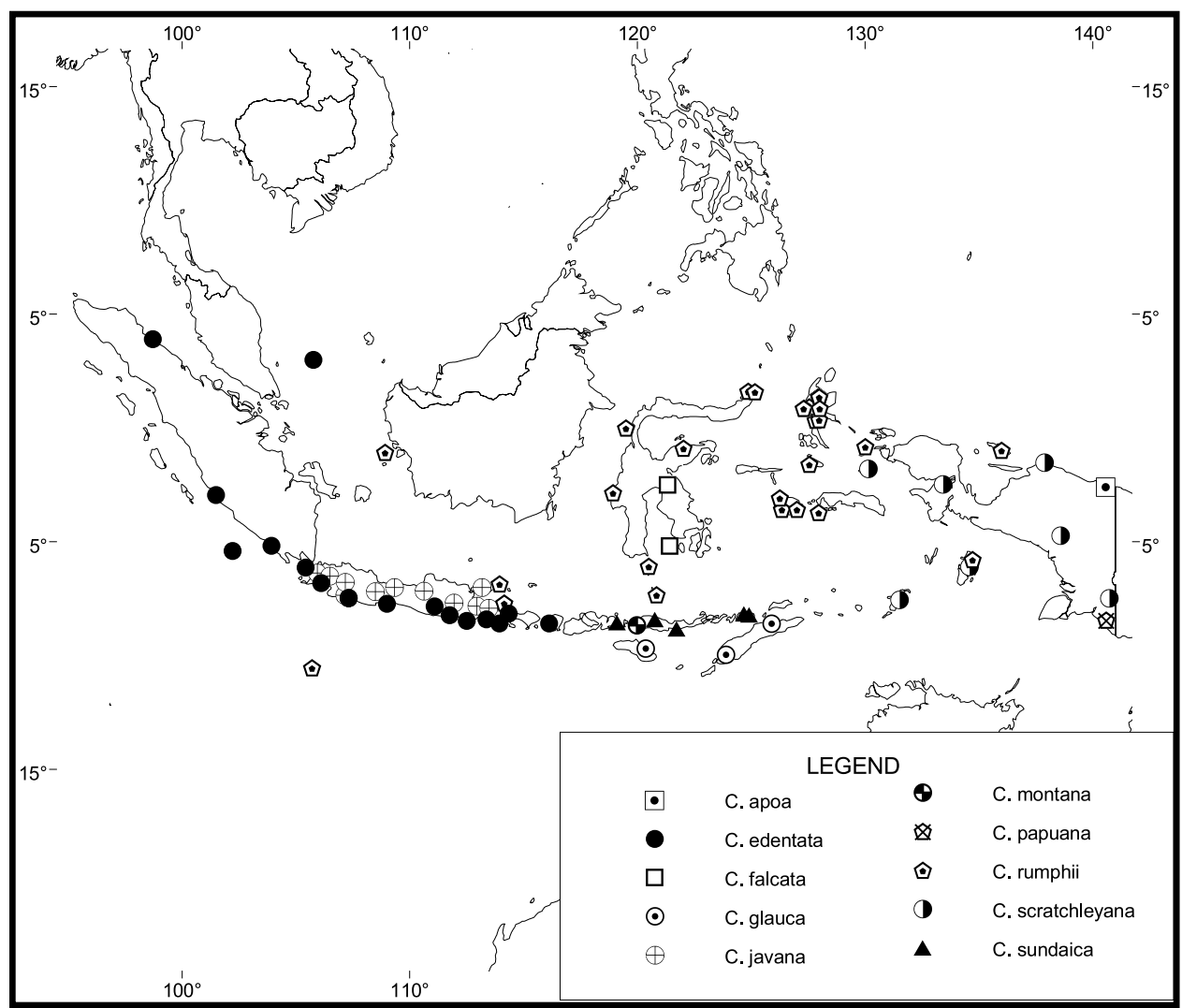

Fig. 1. Distribution of the genus Cycas in Indonesia. 
Although the reduced lateral spines on the megasporophyll are given as a diagnostic character, some cultivated plants have shown distinct small lateral teeth on the sides of the apical spine on the megasporophyll. However, these teeth are not present on the main part of the lamina.

Distribution and habitat: known from northern coastal New Guinea, from the Huon Peninsula west to the Jayapura Regency (Fig. 1). This species occupies much the same geographic range as C. rumphii in this area, and detailed field study would be required to determine the controls on distribution. Cycas rumphii is, however, a primarily littoral species, whereas C. apoa apparently occurs away from the littoral zone.

This species and C. scratchleyana were included in subsection Rumphiae by Hill (1994a) on the basis of the limited and apparently mixed seed collections then available. At that time, section Cycas was not known to extend beyond Malaysia. More recent, collections and further studies have clearly established placement of these species and C. javana in subsection Cycas (sensu Hill 1995b), and dramatically extended the known range of this subsection.

Sporadic and scattered, in more or less closed mesophyll forest in wet lowland areas, sometimes in seasonally inundated sites but more often on low ridges.

Conservation status: not considered to be at risk. Recommended status would be LC. Ver 3.1:IUCN (2001) status is NT (Donaldson 2003) for Indonesia and PNG.

Selected specimens examined: PAPUA NEW GUINEA: West Sepik: Kasiman Village, Ferrero s.n., 1993 (NSW). Morobe: Quembung trail, Clemens 8104, 2 Apr. 1938 (A[n.v.], BRI, CANB, L); Sattelberg, Clemens 751, 31 Oct 1935 (G).

2. Cycas scratchleyana F.Muell., Victorian Naturalist 2(2): 18-19 (1885). Cycas circinalis subsp. papuana var. scratchleyana (F.Muell.) J.Schust., Pflanzenr. 99: 70-71 (1932).

Type: Papua New Guinea, Central: "New Guinea, Mt. Bedford, Jala River, DedouriCountry", W. Armit s.n. (holo MEL; iso K).

Literature: Thistleton-Dyer (1888 as a form of C. rumphii), Lauterbach (1900 as C. circinalis in part), White (1923, as C. circinalis), de Laubenfels \& Adema (1998), Hill (1994a).

Illustrations: Mueller (1885b), Schuster (1932, fig 10K), Hill (1994a, fig. 13).

Etymology: honouring English military engineer and colonial administrator Sir Peter Henry Scratchley (1835-1885), Special Commissioner for the Territory of New Guinea from 1884-1885.

Vernacular: bico (Ekor village, Halmahera), enge-enge (Mekeo language, Maipa village), notuweh (Medino village), kataki (Dsimakani language, Lake Murray area) (Hill 1994a).

Stems arborescent, to 4, rarely $7 \mathrm{~m}$ tall, 12-20 cm diam. at narrowest point. Leaves bright green or deep green, highly glossy, 170-310 cm long, flat (not keeled) in section (opposing pinnae inserted at $180^{\circ}$ on rachis), with 160-300 leaflets, with white tomentum shedding as leaf expands; rachis usually terminated by a spine or paired leaflets; petiole $25-70 \mathrm{~cm}$ long (20-30\% of total leaf), glabrous, spinescent for $80-100 \%$ of length; basal leaflets not gradually reducing to spines. Median leaflets simple, strongly discolorous, $220-310 \mathrm{~mm}$ long, $10-16 \mathrm{~mm}$ wide, inserted at $60^{\circ}$ to rachis, decurrent for $1 \mathrm{~mm}$, narrowed to $2.5 \mathrm{~mm}$ at base (to $20 \%$ of maximum width), $16 \mathrm{~mm}$ apart on rachis; section flat; margins slightly recurved and undulate; apex softly acuminate, not spinescent; midrib raised above, raised below. Cataphylls linear, pungent, pilose, 
50-100 mm long. Pollen cones narrowly ovoid or fusiform, yellow to brown (pale), 20-25 cm long, 10-13 cm diam.; microsporophyll lamina firm, not dorsiventrally thickened, c. $35 \mathrm{~mm}$ long, c. $20 \mathrm{~mm}$ wide, fertile zone c. $27 \mathrm{~mm}$ long, sterile apex c. $6 \mathrm{~mm}$ long, raised; apical spine prominent or rudimentary, sharply upturned, $2-6 \mathrm{~mm}$ long. Megasporophylls c. $28 \mathrm{~cm}$ long, orange-brown tomentum; ovules 2-8, glabrous; lamina ovate to lanceolate, $45-80 \mathrm{~mm}$ long, $38-50 \mathrm{~mm}$ wide, regularly dentate; with 28-40 soft lateral spines 5-8 $\mathrm{mm}$ long, $1 \mathrm{~mm}$ wide; apical spine distinct from lateral spines, 25-30 mm long, $3 \mathrm{~mm}$ wide at base. Seeds flattened-ovoid, $43-55 \mathrm{~mm}$ long, 32-40 mm wide; sarcotesta orange or orange-brown, not pruinose, 5-7 mm thick; fibrous layer present; sclerotesta smooth; spongy endotesta absent. Fig. 2.

Historical notes: described in 1885 by German-born but pre-eminent Australian colonial botanist Sir Ferdinand Jacob Heinrich von Mueller (1825-1896). Collection details cited were "On Mount Bedford, Jala-River, Dedouri-Country; W. Armit." The single specimen known, which can be accepted as the holotype, is MEL 68059 (photo NSW), collected by W.E. Armit on the Argus Expedition into the hinterland of Port Moresby in 1883. The label reads as cited by Mueller, without the "On" preface, although Mount Bedford and Jala River were treated as separate localities by Mueller in a listing of Armit collections appended to the protologue. The label was also written entirely in Mueller's hand. Schuster cited "Mount Bedford, Jala-River (Rev. James Chalmers in Herb. Sidney); Dedouri-Country (W. Armit in Herb. Sidney)." None of these specimens can be found in NSW. An isotype, sent by Mueller, is held by K.
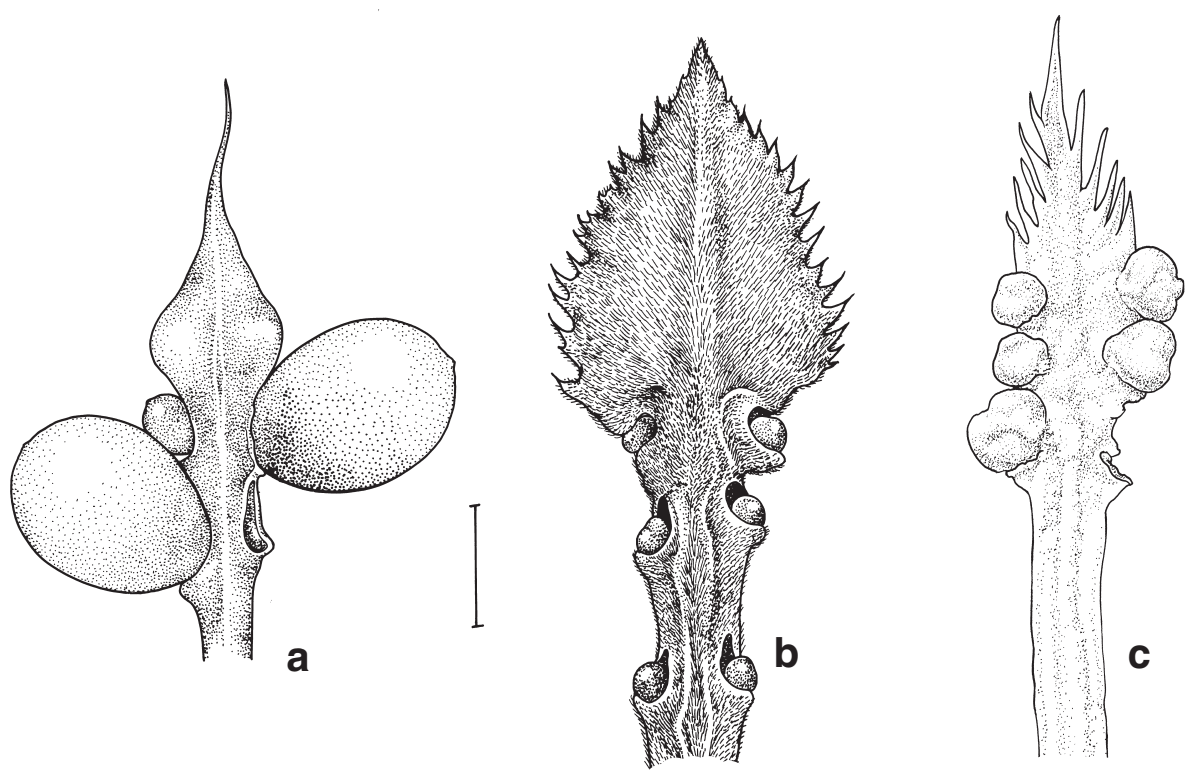

Fig. 2. Comparison of female sporophylls. a, Cycas apoa. b, Cycas scratchleyana. c, Cycas javana (a from Ferrero s.n. by N. Oram, b from Taylor 11 by N. Oram, c from slide, cult. Cibodas Botanic Garden, Java, Indonesia by C. Wardrop). Scale bar $=2 \mathrm{~cm}$. 
This species has been poorly understood since it was first described. Subsequent authors have generally ignored the name $C$. scratchleyana, most commonly using the name C. circinalis (Lauterbach 1900, White 1923). Thistleton-Dyer (1888) regarded it as a form of C. rumphii. The treatment by Schuster (1932) regarded C. scratchleyana as a variety of $C$. circinalis within subspecies papuana (F.Muell.) Schuster, effectively combining the three subsections of section Cycas in a single species.

Schuster's treatment has not been generally followed, although attempts to follow it in the Pacific were made by Smith (1979) and Kanehira (1938). More recently, there has been a tendency to apply the names $C$. rumphii, $C$. circinalis and, to a lesser extent, C. media R.Br. somewhat uncritically, including to specimens of C. scratchleyana (Paijmans 1976; specimen determinations in LAE, CANB, L, BO). The treatment of Cycas by de Laubenfels and Adema (1998) recognises C. scratchleyana, but with unclear circumscription and citing material that clearly does not belong (e.g. Warburg 21129 from New Britain). Mistaken inclusion of C. scratchleyana in subsection Rumphiae by Hill (1994a) is discussed above under C. apoa.

Distinguishing features: nearest to C. apoa, from which it is distinguished as discussed above. Distinguished within the genus by the relatively large, ovate megasporophyll lamina with numerous short to medium-length lateral spines, the long, narrow, thin leaflets that lack hypodermis and are frequently very strongly undulate, and the usually wholly spinescent petiole. Adaxial mesophyll is continuous across the usually narrow and strongly raised midrib, and abaxial mesophyll also is sometimes continuous. Some specimens display broader, harder leaflets with scattered laminar hypodermis, probably as an environmental response to higher light conditions. Some specimens from around Port Moresby also show somewhat narrower, harder and slightly keeled leaflets with a harder and glossier cuticle, and are interpreted as the products of hybridism with C. campestris K.D.Hill.

Distribution and habitat: widespread in eastern New Guinea, extending from nearcoastal sites to foothills, from Milne Bay west to western Irian Jaya and Maluku, apparently mainly on the southern catchments (Fig. 1). Collections from Irian Jaya are limited, and the species is probably more abundant than is suggested. The range also may extend further to the west. Often a species of higher elevations (to over $900 \mathrm{~m}$ ), usually on slopes or ridges in more or less closed, moist forests, but also extending to similar forests on stabilised calcareous coral-sand dune country and nearby headlands, particularly in the east of the range.

Plants from the far west of the known range (Buwalda 4622) from the Tanimbar group) show a somewhat narrower megasporophyll lamina, but still with the distinct dentition of C. scratchleyana. These may represent regional variation, some degree of intergradation with $C$. javana, or another taxon. Widespread regional political unrest has rendered this locality off limts for some time now. These plants require further investigation, but are here treated as a regional variant of C. scratchleyana until such time as they can be adequately investigated.

Conservation status: not considered to be at risk. Recommended status would be LC. Ver 3.1:IUCN (2001) status is NT for Indonsesia and PNG. (Donaldson 2003).

Selected specimens examined: PAPUA NEW GUINEA: Milne Bay: Biniguni camp, Gwariu River, Brass 23830, 5 Aug 1953 (A[n.v.], CANB, K, L); track between Tutubea and Lake Lavu, Fergusson Island, Esa'ala Subdistrict, Croft et al. LAE 68785 A, 12 Nov 1976 (LAE, BRI, CANB, 
K, L); top of Pini Range, Sagarai, Alor Subprovince, Gideon LAE76964, 3 Mar 1984 (LAE, K, L); $2 \mathrm{~km}$ inland of Medino, N coast of Cape Vogel Peninsula, Hoogland 4750, 15 Sep 1954 (CANB, BM, BO, BRI, K, L, LAE); Sewa Bay, Normanby Island, Ese'ala Sub-district, Lelean and Streimann LAE 525246, 21 Oct 1971 (ALE); Biniguni, Raba Raba Subdistrict, Streimann NGF28556, 27 Jun 1972 (LAE[n.v.], CANB, K, L); near Kwagira, Taylor 11, 26 Sep 1954 (CANB). Central: Kubuna, Brass 5643, Nov 1943 (BRI, BO); near Maipa airstrip, Maipa village, Kairuku Subdistrict, Darbyshire 907, 8 Sep 1962 (CANB, K, L, LAE); on ridge below Boridi Village, Port Moresby Subdistrict, Foreman and Vinas LAE60256, 1 Oct 1973 (LAE, CANB, K, L); logging road near Kuriva sawmill, Hiritano Highway road, Moresby Subdistrict, Larivita and Maru LAE70598, 1 Sep 1976 (LAE, BRI, K, L, NSW); Mekeo district, White 794, Jul-Aug 1918 (BRI); Brown River timber reserve, Womersley \& Van Royen NGF5872, 24 Jun 1954 (BO). Gulf: near Malalaua, Craven and Schodde 933, 2 Mar 1966 (CANB, K, L, LAE); above Purari, $63 \mathrm{~km}$ at $65 \mathrm{deg}$. from Baimuru, Baimuru Subdistrict, Croft et al.LAE 61174, 27 Mar 1974 (LAE, BRI, CANB, K, L); Mina River, Kikori Subdistrict, Womersley NGF46475, 28 Mar 1974 (LAE, BRI, CANB, K, L). Western: Fly River, 528 mile camp [Palmer Junction], Brass 6752, May 1936 (A, BM, BO, BRI, K, L, LAE); Kiunga, Kiunga Subdistrict, Streimann and Lelean NGF34119, 13 Sep 1972 (LAE[n.v.], CANB, L).

INDONESIA: Papua: Mamberamo River nr Albatros bis, Docters van Leeuwin 9623, Jul 1926 (BO); Jaba, Wissel Lake region, Eyma 5451, 23 Nov 1939 (BO);Merauke District: path from Lake Wam to Wam River, van Royen 4769, 21 Aug 1954 (L, CANB, KEP K). Radjah Ampat, Waigeo Island, Siam River on eastern peninsula upstream of Wekasan, van Royen 5297, 25 Jan 1955 (L, CANB). Maluku: Aru, Kobroor, Durbaum s.n., Aug 1995 (NSW); Halmahera, Ekor, base of Gunung Panjang, Vogel 3136, 24 Sep 1974 (L, CANB); Tanimbar, Jamdona Is., Otimmer, Buwalda 4622, 5 Apr 1938 (BO, K, L). West Papua: Misool Is., Sorong [ $1^{\circ} 48^{\prime} \mathrm{S} 130^{\circ} 08^{\prime} \mathrm{E}$ ], on road to Tip, Pleyte 978, 21 Sep 1948 (BO, BRI, K);

3. Cycas javana (Miq.) de Laub., in D.Y.Wang, Cycads China: 65 (1996). Cycas circinalis var. javana Miq., Monogr. Cycad.: 28. Tab. 1, fig. t \& u, Tab. II, fig. E1 (1842).

Type: Indonesia, Java, Blume 1089 (holo L, 2 sheets).

Literature: De Candolle (1868 as C. circinalis var. javana), Miquel (1868 as C. rumphii).

Illustrations: Miquel (1842 as C. circinalis var. javana) de Laubenfels (in Wang 1996, figs 1-5), de Laubenfels and Adema (1998, fig 2).

Etymology: from the island of Java, with the Latin suffix -ana, a connection, referring to its occurrence on and initial collection from Java.

Stems arborescent, 2-4 m tall, 15-20 cm diam. at narrowest point. Leaves dark to mid green, highly glossy, faintly bluish as expanding, to $205 \mathrm{~cm}$ long, flat (not keeled) in section (opposing pinnae inserted at $180^{\circ}$ on rachis), with c.146 leaflets, with brown or orange-brown tomentum shedding as leaf expands, terminated by a spine to $6 \mathrm{~mm}$ long or paired leaflets; petiole 30-60 cm long (15-25\% of total leaf length), glabrous, spinescent for 40-90\% of length; basal leaflets not gradually reducing to spines. Median leaflets simple, strongly discolorous, $240-370 \mathrm{~mm}$ long, $10-15 \mathrm{~mm}$ wide, inserted at c. $50^{\circ}$ to rachis, narrowed to $2.5-6 \mathrm{~mm}$ at base (to $20-35 \%$ of maximum width); section flat; margins slightly to moderately recurved; apex acute, not spinescent; midrib raised above, raised below. Cataphylls linear, soft, rich orange-brown pilose. Pollen cones ovoid, orange or brown; microsporophyll lamina firm, not dorsiventrally thickened, apical spine prominent, sharply upturned. Megasporophylls 22-36 cm long, browntomentose, tomentum persistent; ovules 2-8, glabrous; lamina lanceolate, $60-100 \mathrm{~mm}$ 
long, 11-30 mm wide, regularly dentate; with 12-30 pungent lateral spines 5-20 mm long, 1-2 mm wide; apical spine distinct from lateral spines, $10-65 \mathrm{~mm}$ long, $1.5-3 \mathrm{~mm}$ wide at base. Seeds not seen. Fig. 2 .

Historical notes: described in 1842 as a variety of $C$. circinalis by Dutch botanist Miquel. Miquel later subsumed this variety into C. rumphii, and no further note was made of it until the present decade when de Laubenfels raised this to species in 1996. The treatment of this species by de Laubenfels and Adema (1998) is essentially correct.

Distinguishing features: the lack of any spongy endotesta and the narrow, regularlytoothed megasporophyll lamina distinguish this species.

Distribution and habitat: Cycas javana is apparently a Javan endemic (Fig. 1). Plants occur in closed evergreen forest, inland, often near streams in mountain areas. Populations also persist in disturbed areas.

Conservation status: much of the original habitat of this species has been cleared for agriculture. Although healthy populations remain in some higher areas, the appropriate recommended status would be NT. Ver 3.1:IUCN (2001) status is DD (Donaldson 2003).

Selected specimens examined: INDONESIA: Jawa Timur: Kangean, [--] Tanbajangan [Tambayangan] 22 m, Backer 27471, 1920 (L, BO); Kangean Is., NE of Java, Hoogerwerf 235, 1954 (L); Besoeki Poeger [Besuki Puger], [G.] Watangan [8²5'S 113² 28'E], Koorders 1564 B, 21 Aug 1889 (L, BO). Jawa Tengah: Prov. Banjoemas, Pringombar, Koorders 1563, 20 Nov 1891 (L, BO); Prov. Preangar, Temarang [?Semarang], Kedoengdjati [ $7^{\circ} 10^{\prime} \mathrm{S} 110^{\circ} 38^{\prime} \mathrm{E}$ ], Koorders 24990 B, 19 Sep 1896 (L).Jawa Barat: Banham Tusschen Malingping [6 $6^{\circ} 48^{\prime} \mathrm{S} 106^{\circ} 01^{\prime} \mathrm{E}$ ] en Penjarroengan [Panggarangan $6^{\circ} 53^{\prime} \mathrm{S} 106^{\circ} 12^{\prime} \mathrm{E}$ ], Backer 1476, 17 Jun 1911 (L); Tjialin a/d Tjitarik [6 $6^{\circ} 20^{\prime} \mathrm{S}$ $107^{\circ} 27^{\prime} \mathrm{E}$ ], Res Oreabgar, 500 m, Bakhuizen v.d. Brink 5086, 21 Dec 1920 (L); G. Talagabodas $\left(7^{\circ} 12^{\prime} \mathrm{S} 108^{\circ} 28^{\prime} \mathrm{E}\right)$, Ken $\mathrm{VH}(\mathrm{L})$; near Cibaraja village, along stream, $7^{\circ} 22.164^{\prime} \mathrm{N} 107^{\circ} 08.580^{\prime} \mathrm{E}$, Lindstrom 174, 175 (live voucher plants at Nong Nooch Tropical Botanical Gardens); cult. in Cibaraja village, coll. nearby, Lindstrom 173, Apr 1999 (NSW, UBC); Res Preangar, Reg Tjabareno estate, by pelaboean Ratoe [Pelabuhan Ratu 659'S 106 35'E], Pottinga s.n., 1 Oct 1923 (L, BO); Kuripia [? Koeripan - near Bogor], leg. ign. (L); Kuripau [? Koeripan - near Bogor], leg. ign. (L); Up Kuripian [? Koeripan - near Bogor], leg. ign. [Blume?] 1079 (L).

Cult.: hort. Bogor, Stolk 149 (BO, L)

\section{Cycas montana A.Lindstr. \& K.D.Hill, sp. nov.}

Inter species indonesienses combinatione characterum sequentium distinguitur: folia viridia (non glauca), foliolis rigidis angustis, petiolis tomentosis, fructus non spongiosus.

Type: Indonesia, Flores, Mangarai province, Nggoang district, Ndara, Wae Moto village, $400 \mathrm{~m}$, Lindstrom 248, 27 Apr 2000 (Holotype BO, iso UBC).

Etymology: from the montain habitat.

Vernacular: tulumpu, watai (unidentified languages).

Stems arborescent, to $1.5 \mathrm{~m}$. tall, 30-35 cm diam. at narrowest point. Leaves deep green, glossy, 223-248 cm long, 144-151 leaflets, with persistent brown tomentum; petiole $63-72 \mathrm{~cm}$ long (25-30\% of total leaf), spinescent for c. $20 \%$ of length; basal leaflets not gradually reducing to spines, to $230 \mathrm{~mm}$ long. Median leaflets simple, strongly discolorous, $230-248 \mathrm{~mm}$ long, 8-10 $\mathrm{mm}$ wide, decurrent for $7 \mathrm{~mm}$, narrowed to 
3-4 $\mathrm{mm}$ at base (30-40\% of maximum width), 10-15 $\mathrm{mm}$ apart on rachis; section slightly keeled; margins distinctly recurved; apex acute or aristate, spinescent; midrib flat above, raised below, narrow. Cataphylls narrowly triangular, soft. Pollen cones not seen. Megasporophylls 20-35 cm long, tomentum orange, persistent; ovules 2-6, glabrous; lamina lanceolate, $45-100 \mathrm{~mm}$ long, 20-40 $\mathrm{mm}$ wide, shallowly pectinate, with 14-40 pungent lateral spines 9-13 mm long, $1.5 \mathrm{~mm}$ wide; apical spine distinct from lateral spines, 25-40 $\mathrm{mm}$ long, 5-8 $\mathrm{mm}$ wide at base. Seeds ovoid, 50-55 $\mathrm{mm}$ long, 30-45 mm wide; sarcotesta amber-brown, not pruinose; fibrous layer present; sclerotesta smooth, spongy endotesta absent. Fig. 3.

Distinguishing features: Cycas montana is distinguished from other species in the region by the absence of a spongy endotesta, the green (non-glaucous) leaves, the persistent brown tomentum on the petiole, and the stiff, narrow leaflets.

Distribution and habitat: endemic on Flores (Fig. 1), restricted to inland montane forests at higher altitudes.

Conservation status: not thought to be at risk, although not reserved. Recommended Ver 3.1:IUCN(2001) status would be NT.

Selected specimens examined: INDONESIA: Nusa Tenggara Timur: Flores: Ngada province, cult. in Bajawa town, said to originate from nearby montain forest, Lindstrom 253, 29 Apr 2000 (BO, UBC); Ngada province, cult. in Jerebao village, near Bajawa town, said to come from nearby forest, Lindstrom 261, 29 Apr 2000 (BO, UBC); Ngada province, cult. in Wolosambi village, near Bajawa town, said to comefrom nearby forest, Lindstrom 262, 30 Apr 2000 (BO, UBC); Ngada province, Nangamboa village, Ondorrea Mountain Lindstrom 263, 30 Apr 2000 (BO, UBC); Nunang, 650 m, Schmutz 0123, 17 May 1965 (L); Manggarae, Nunang, 650 m, Schmutz SVD 4717, 14 Dec 1980 (L).

Cycas subsection Rumphiae K.D.Hill, Austral. Syst. Bot. 7: 548 (1994a).

Type species: Cycas rumphii Miq., Bull. Sci. Phys. Nat. Neerl. 2: 45 (1839).

This subsection is uniquely defined by the presence of a layer of spongy tissue within the seed. Another potentially synapomorphic character defining this group is the 2-year seed maturation period, although this has been confirmed only for C. seemannii A. Br., C. thouarsii R. Br. Ex Gaudich.and C. bougainvilleana K.D.Hill. All other species of Cycas for which data is available have a maturation period of less than one year.

Distribution is very wide, extending from Africa to Fiji and Tonga, and from New Guinea north to southern coastal Indochina. Four species occur in Indonesia.

The spongy endotesta causes seeds to be buoyant, and has been proposed as a dispersal mechanism (Dehgan \& Yuen 1983). This dispersal mechanism has been interpreted as a cause of the taxonomic complexity of this group, with successive colonisation events producing the high local variability in some populations and the very different forms sometimes occurring in close proximity (Hill 1994a, Fosberg \& Sachet 1975).

5. Cycas falcata K.D.Hill, Kew Bull. 54(1): 209 (1999).

Type: Indonesia, Sulawesi, Kabaena, Gunung [Mount] Katopi, 18 km NW of Tangkeno, McDonald \& Ismael 4184, 7 Aug 1993 (holo K, iso A, BO, E, KEP, L).

Illustrations: Hill (1999). 


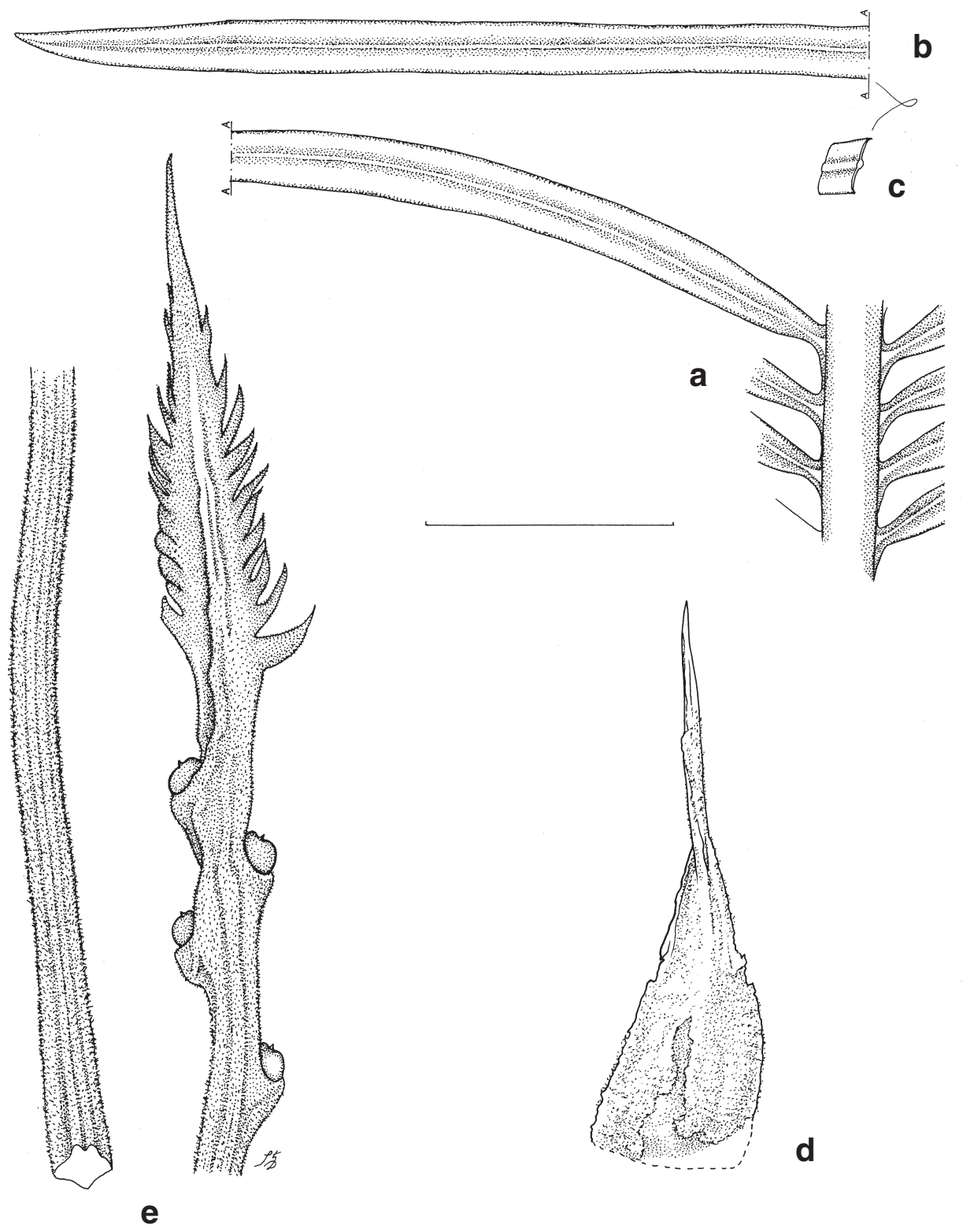

Fig. 3. Cycas montana. a, b, part of leaf. c, cross-section of leaflet. d, cataphyll. e, female sporophyll (all from Lindstrom 248, d, by C. Wardrop ). Scale bar $=5 \mathrm{~cm}$. 
Etymology: from Latin falcatus, falcate or curved in a sickle-shape, from the distinctively curved leaflets.

Stem erect, unbranched or occasionally branching 2 to 3 times at base, to $5 \mathrm{~m}$ tall, $12-30 \mathrm{~cm}$ diam. at narrowest point. Leaves olive-green, glossy, $180-300 \mathrm{~cm}$ long, slightly keeled in section (opposing leaflets inserted at c. $150^{\circ}$ on rachis), with 100-200 leaflets, glabrous; rachis terminated by paired leaflets or a spine c. $3 \mathrm{~mm}$ long; petiole $27-62 \mathrm{~cm}$ long (20-35\% of total leaf length), glabrous, spinescent for $80-100 \%$ of length; basal leaflets not gradually reducing to spines. Median leaflets simple, glabrous, moderately discolorous, often strongly falcate, $170-300 \mathrm{~mm}$ long, $7.5-13 \mathrm{~mm}$ wide, inserted at $60-70^{\circ}$ to rachis, decurrent for $5-7 \mathrm{~mm}$, narrowed to $3-4 \mathrm{~mm}$ at base (to $45 \%$ of maximum width), 11-17 mm apart on rachis; keeled in section; margins slightly recurved; apex acuminate, not spinescent; midrib strongly raised above, green, slightly raised below; leaflets tapering gradually from near midpoint to base; tomentum loose and shed early. Cataphylls broadly triangular, soft, $40-70 \mathrm{~mm}$ long, with short, erect mid-brown indumentum. Pollen cones not seen. Megasporophylls 19-27 cm long, mid-brown-tomentose; ovules 4-6, glabrous; lamina narrowly triangular, $60-70 \mathrm{~mm}$ long, 22-32 mm wide, shortly pectinate, with 16-28 more or less pungent lateral spines 7-12 mm long; apical spine distinct from lateral spines, $15-28 \mathrm{~mm}$ long, $2.5-4 \mathrm{~mm}$ wide. Seeds flattened-ovoid, 42-46 mm long, 25-34 mm wide; sarcotesta orangeyellow, not pruinose, fibrous layer absent; sclerotesta not or weakly apically crested; thin spongy layer present. Fig. 4.

Distinguishing features: the spongy endotesta places this species unmistakably in the Cycas rumphii group (subsection Rumphiae, Hill 1994a), although it differs markedly in many other respects. The small seeds are not typical of this group, and neither are the distinct long lateral spines on the megasporophyll lamina, the keeled leaves or the narrow, falcate pinnae.

Distribution and habitat: Cycas falcata is known from two localities on the main island of Sulawesi and from Kabaena Island off the south-eastern coast of Sulawesi (Fig. 1). It occurs in habitats ranging from closed forest to open short tree savanna with grasses dominant, in full sun to heavy shade, over limestone or serpentinite substrates.

The habitat of this species is quite different to the habitats of other species in the C. rumphii group, which generally occur in near-coastal situations (Hill 1994a). Aquatic dispersal and the consequent coastal distribution are general features of this group. The departure of this species from the general state can be best regarded as an evolutionary advance, represented by the colonisation of a new and different site. Although many cycads are either calciphiles or serpentiniphiles (Hill 1995b, 1998), such habitat preference can be seen from this example to be derived rather than ancestral conditions, and is a condition that has arisen independently on more than one occasion.

The deeply dentate or shortly pectinate megasporophyll is another feature not known elsewhere in subsection Rumphiae. Similar megasporophylls occur in the forest species C. macrocarpa Griff. from Thailand and peninsular Malaysia, and C. riuminiana Porte ex Regel from the Philippines. These however lack the spongy endotesta and possess a fibrous sarcotesta not evident in subsection Rumphiae. A hybrid origin between one species of subsection Rumphiae and one of subsection Cycas cannot be demonstrated at this stage, but is not out of the question. 
Conservation status: although probably not immediately threatened, this species is of apparently limited distribution and potentially vulnerable in the longer term. On the basis of a preliminary evaluation, the appropriate Ver 3.1:IUCN (2001) status would be NT. Further field study is required to fully assess the conservation status of this species and indeed of most Asian cycad species. Current Ver 3.1:IUCN (2001) status is DD (Donaldson 2003).

Selected specimens examined: INDONESIA: Sulawesi Selatan: Soroako - Wasuponda road, km 19, van Balgooy 3930, 7 Jul 1979 (L, BO); Mt Molinowe, 14 km from Wasuponda between Wasuponda and Soroako, Hennipman 6133, 7 Jul 1979 (BO, L, A); S of Wasuponda, SW of Soroako, de Vogel 6304, 16 Jul 1979 (L, BO); S. shore of Lake Matano, de Vogel 5734, 12 Jun 1979 (L, BO, BRI). Sulawesi Tenggara: around Opa Swamp, Mt Makaleo, Prawiroatmodjo \& Soewoko s.n. and 1757, 13 Nov 1978 (L ex BO).

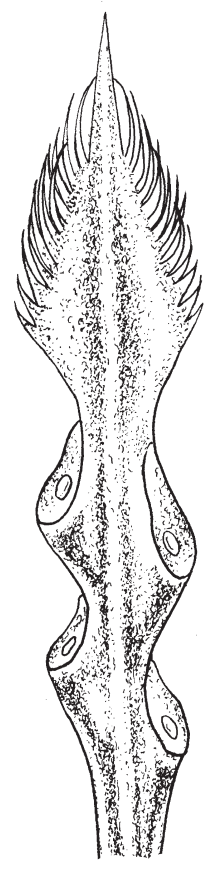

a

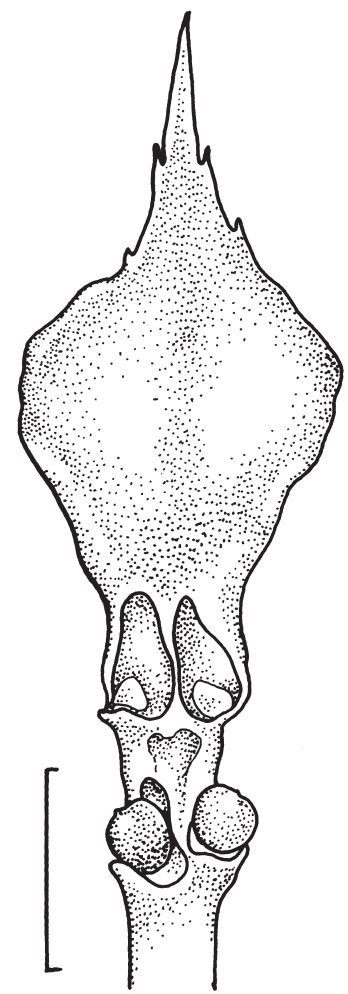

b

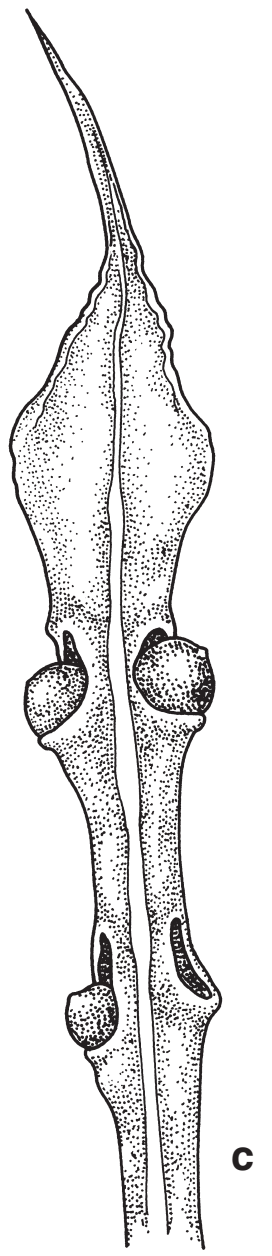

C

Fig. 4. Comparison of female sporophylls. a, Cycas falcata. b, Cycas rumphii. c, Cycas edentata (a from McDonald \& Ismael 4184 by L.McGurr, b from van Royen 3300 by N. Oram, c from Hill 4627 by N. Oram). Scale bar $=2 \mathrm{~cm}$. 
6. Cycas rumphii Miq., Bull. Sci. Phys. Nat. Néerl. 2: 45 (1839).

Lectotype: Plate 23 in Rumphius (1741), fide Lindstrom (2002).

Cycas celebica Miq., Bull.Sci. Phys. Nat. Neerl.2: 45 (1839).

Lectotype: Plate 21 in Rumphius (1741), fide Lindstrom (2002).

[Cycas recurvata Blume ex. J. Schuster., Pflanzenr. 99:74 (1932); name only, in syn. Cycas rumphii]

[Cycas speciosa D. Don, Proc.Linn.Soc. 1:53-56 (1840); name only, in syn. Cycas rumphii] [Cycas sundaica Miq. ex J. Schust., Pflanzenr. 99: 74 (1932); name only, in syn. Cycas rumphii]

Literature: Lemaire (1864 as C. rumphii and C. celebica), Lauterbach (1900 as C. circinalis), Stapf (1916), Backer (1925), Ochse (1931), Schuster (1932), Kanehira (1938), Backer \& Bakhuizen van den Brink (1963), Peekel (1984), Hill (1994a), de Laubenfels and Adema (1988, in part).

Illustrations: Miquel (1852), Warburg (1900), Schuster (1932), Kanehira (1938),Peekel (1984), Hill (1994a).

Etymology: honouring German-born Dutch naturalist Rumphius (Georg Eberhard Rumpf, 1628-1702), military officer with the Dutch East India Company in Ambon, 1652-1657, then with the civil merchant service of the Dutch East India Company.

Vernacular: nufuès (Biak); queen sago (English); haji, hajo, intalappana, pakoe laut (sea fern), paku gajah, paku laut (Malay); sumo (Wapi); ftoi (Weda); bakutu, djoedjaroet, djudjarn, madjong utu, pekis rady, utta niwel, utta nuer (unidentified languages) (Hill 1994a, Pant 1962, Schuster 1932, Bonta \& Osborne 2007).

Typification: the original description of C. rumphii is based on 'Olus Calappoides' or 'Sajor calappa' of Rumphius, Herb. Amboinense., Lib. 1, Cap.XX excl. planta Celebica 1741. Most Rumphius specimens were lost in a ship wreck while en route to Europe (Stafleu \& Cowan 1983). This leads to the conclusion that Miquel did not have either live plants or herbarium specimens available and that he relied strictly on the plates in Rumphius's work for his description. However, Hill (1994a) pointed out that one of the illustrations of Rumphius (1741) shows rather distinct lateral teeth on the megasporophyll. This does not entirely accord with other collections from the Moluccas and the larger teeth may be the artist's interpretation. De Laubenfels and Adema (1998) pointed out that recently collected material of C. rumphii cited by Hill (1994a) shows variation in the megasporophylls in that some have teeth while others do not. Besides the megasporophyll, other characters in these illustrations are inconsistent with collections from the type locality; specifically the overall shape of the megasporophyll lamina, the short spine on the megasporophyll tip, the clearly visible spines on the petiole and the fact that the seeds do not show any spongy layer. All of these characters could be the artist's interpretation, but it is more probable that the drawing was done from different plants, possibly even different species. Plate 22, overall much more resembles $C$. scratchleyana, a species that is found in the area and on neighboring Ceram. Both plates have been cited as the type (Hill 1994a; de Laubenfels, 1998). Miquel's description of C. rumphii initially encompassed Plates 22 and 23 of Rumphius. Later (1839) he placed his C. celebica (plates 20 and 21) into synonymy with C. rumphii. As Miquel's initial concept of C. rumphii was based on plates 22 and 23 these plates should serve as the type. However, recent studies of living specimens and 
herbarium material indicate that these plates (22, a female plant and 23, a male plant) represent two distinct species. Plate 23 was designated as the lectotype of C. rumphii by Lindstrom (2002) for two reasons. First, recently collected material of a male plant from Ambon (Robinson 563, Ambon, Wae) matches well with the illustration on Plate 23. Additionally, the current usage of the name C. rumphii is in agreement with the illustration on Plate 23 while Plate 22 matches C. scratchleyana. Choosing Plate 22 as the type would cause major and unnecessary nomenclatural instability while selecting Plate 23 as the type increases nomenclature stability in the genus. Based upon examination of recently collected material, (see specimens examined), C. celebica must correctly stay as a synonym of C. rumphii. De Laubenfels' (1998) recognition of C. celebica as a distinct taxon was evidently based upon the lack of spines on the petiole in the type illustration. This is correct in the type drawing but not consistent within several populations examined in Sulawesi.

Stems arborescent, to $3(-10) \mathrm{m}$ tall, $11-20 \mathrm{~cm}$ diam. at narrowest point. Leaves bright green, highly glossy, $150-250 \mathrm{~cm}$ long, flat (not keeled) in section (opposing pinnae inserted at $180^{\circ}$ on rachis), with 150-200 leaflets, with orange tomentum shedding as leaf expands; rachis consistently terminated by paired leaflets; petiole $35-60 \mathrm{~cm}$ long (20-30\% of total leaf), glabrous, spinescent for $0-100 \%$ of length; basal leaflets not gradually reducing to spines, $190 \mathrm{~mm}$ long. Median leaflets simple, strongly discolorous, $220-320 \mathrm{~mm}$ long, $12-16 \mathrm{~mm}$ wide, inserted at $70-85^{\circ}$ to rachis, decurrent for 5-8 $\mathrm{mm}$, narrowed to $4.5-7 \mathrm{~mm}$ at base (to $35-50 \%$ of maximum width), $15-19 \mathrm{~mm}$ apart on rachis; section flat; margins slightly recurved; apex acute, not spinescent; midrib flat above, raised below. Cataphylls narrowly triangular, soft, shortly pilose. Pollen cones fusiform, yellow to brown (pale), $35-55 \mathrm{~cm}$ long, $10-15 \mathrm{~cm}$ in diameter; microsporophyll lamina firm, dorsiventrally thickened, apical spine rudimentary, sharply upturned, 2-5 mm long. Megasporophylls $18-32 \mathrm{~cm}$ long, white-tomentose or yellow-tomentose; ovules 2-6, glabrous; lamina lanceolate, $50-75 \mathrm{~mm}$ long, $25-35 \mathrm{~mm}$ wide, obscurely dentate; with c. 12 soft lateral spines $0-4 \mathrm{~mm}$ long, $0-2 \mathrm{~mm}$ wide; apical spine distinct from lateral spines, $10-25 \mathrm{~mm}$ long. Seeds flattened-ovoid, $45 \mathrm{~mm}$ long, $30 \mathrm{~mm}$ wide; sarcotesta orange-brown, not pruinose; $3-4 \mathrm{~mm}$ thick, fibrous layer absent; sclerotesta apically crested; spongy endotesta present. Fig. 4.

Historical notes: although first legitimately described in 1839 by Dutch botanist Miquel, the existence of a distinct Malesian taxon was first recognised by Roxburgh (1832: 747), on the basis of plants in cultivation in the Calcutta Botanic Gardens. He recognised that two taxa were present, treating one as C. circinalis and describing the other as a new species C. sphaerica Roxb. Roxburgh had, however, mistakenly applied the new name $C$. sphaerica to plants from India belonging to the $C$. circinalis alliance.

The distinct Malesian taxon he then treated under the name C. circinalis, although he had also mixed material of the two taxa under each description.

Miquel's C. rumphii (1839: 45) was based on part of Olus Calappoides of Rumphius (1741) and he was never clear on the specific limits of this taxon, at first separating material from Sulawesi as C. celebica (1839: 45), and later (1868: 232), combining the two. Miquel also separated material from Timor as C. rumphii var. timorensis (1841: 125), and from Java as C. circinalis var. javana (1842: 28). In addition, he at first recognised Roxburgh's C. sphaerica (1843: 693), apparently on the basis of Roxburgh's published account and without realising the confusion with C. circinalis. He later (1851: 32) correctly noted Roxburgh's confusion, and placed C. sphaerica in the synonymy of 
C. circinalis, although later still (1868: 230), he again recognised C. sphaerica at specific rank. At the same time (1868: 232), he placed C. celebica and C. circinalis var. javana in C. rumphii, with no mention of C. rumphii var. timorensis.

Warburg (1900) also recognised the presence of a coastal taxon in New Guinea (including the Province of Papua, Indonesia), assigning it to C. rumphii. This taxon has also been assigned to C. circinalis (White 1923).

Distinguishing features: distinguished by the broad, falcate, hard, glossy leaflets with relatively broad bases, present but discontinuous laminar hypodermis, the relatively long and usually wholly spinescent petiole, the male sporophyll lacking a distinct terminal spine (Fig. 5.) and the narrowly triangular megasporophyll lamina with a slender apical spine (10-25 mm long) and reduced lateral spines. Adaxial mesophyll is usually continuous across the moderately broad and rounded midrib, but sometimes interrupted by the midrib in the east of the range. This may be due to genetic admixture of C. bougainvilleana from further to the east. The condition of reduced lateral spines also occurs in C. edentata, and related taxa from Philippines, Malaysia and the Indian Ocean. The latter taxa (not all treated herein) are, however, distinguished as a group by the lack of the apical crest on the seed.

Distribution and habitat: Cycas rumphii has been poorly understood in the past. Recent recognition of a number of related species has allowed clarification of its identity, and clear delineation of its distribution (Fig. 1). As now understood, C. rumphii has a distribution centred on the Moluccan island group (Maluku, or the Spice Islands) extending east into Indonesian Papua and a short way along the north coast of Papua New Guinea, and north to Sulawesi. In the west, it appears to extend to southern Borneo, north-eastern Java and Christmas Island.

C. rumphii appears to share the ecological preferences of several other taxa in this group, being largely a species of closed woodland or forest on more or less calcareous substrates in near-shore environments.
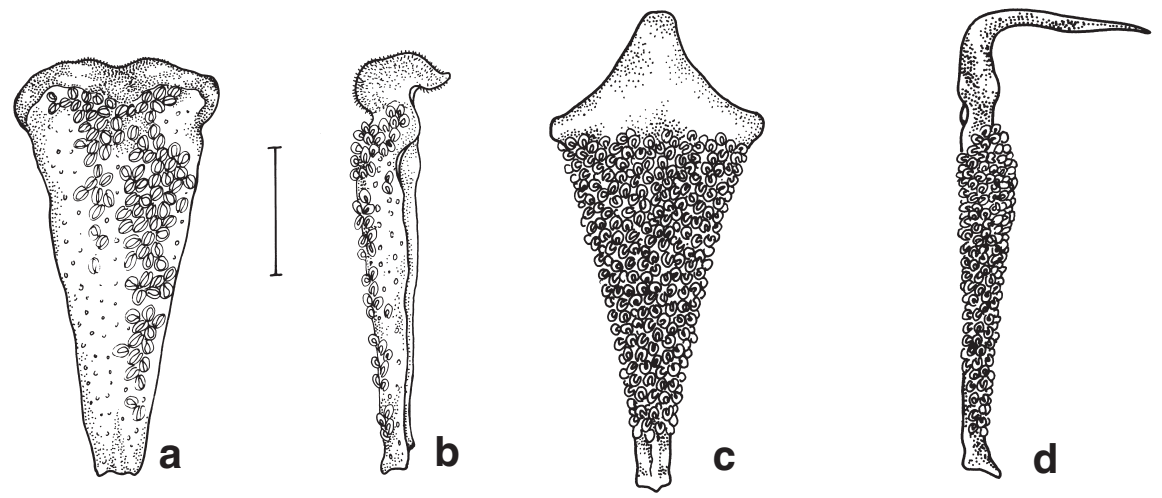

Fig 5. Comparison of male sporophylls. a, b, Cycas rumphii. c, d, Cycas edentata (a, b, from NSW 714722 Claussen s.n., c, d, from Hill 4630 by N. Oram). Scale bar $=1 \mathrm{~cm}$. 
Recognition of C. rumphii as a distinct species has been widely argued, with early discussion very ably summarised by Stapf (1916). Schuster (1932: 74) provided an essentially correct treatment of this species (with the exception of the varieties and subspecies, and the New Caledonian material cited), in contrast to his confused treatment of most other species. The name has been generally accepted subsequently, although misapplications of the name $C$. circinalis to this and related taxa continue (eg. Jones 1993, corrected in $2^{\text {nd }}$ edition, Jones 2002).

Conservation status: the 1997 IUCN Red List of Threatened Plants lists C. celebica as $\mathrm{R}$, although very little is known of this or in fact most occurrences in this region. Once abundant and widespread, this species occurred in coastal sites that have experienced severe pressures from population increase and development. This habitat is also coming under increasing pressure for aquaculture sites. Although probably not immediately threatened, it is potentially vulnerable in the longer term. Ver 3.1:IUCN (2001) status is NT (Donaldson 2003).

Selected specimens examined: AUSTRALIA: Western Australia: Christmas Island, Top of escarpment, Tom's Ridge, $1 \mathrm{~km}$ south of McPherson Point, near northwest point, J. Claussen s.n $\&$ B. Claussen., 07 Mar 2005 (NSW 714734); Just over the edge of the plateau escarpment, 500 m west of Runaway Cave, North East Point, J. Claussen s.n. \& B. Claussen, 24 Feb 2005 (NSW 714722); On the edge of the plateau escarpment, c.1.34 km WNW of Wright Point, East Coast, J. Claussen s.n. \& B. Claussen, 18 Feb 2005 (NSW 714713). Northern Territory: Ashmore Reef. $12^{\circ} 15^{\prime} \mathrm{S} 123^{\circ} 00^{\prime} \mathrm{E}$. Seeds found washed up on beach, probably from Indonesia, Leach s.n., Oct 1996 (NSW).

INDONESIA: [No locality given], Noblick s.n. (FTG); [No locality given], Anon., 13 Nov 1993 (NSW). Jawa Timur: Srigontjo Sen Z. van Malang aan de Zuidree, strand, Backer 3825, 10 Jun 1922 (BO); Kangaean, Soebi, 1.5 m, Backer 20371, 12 Apr 1920 (BO); Kangaean P. Mamboerit $1 \mathrm{~m}$, Backer 27279, 19 Mar 1919 (BO); Sepandjang [c. 8 10' S 112 40' E], Backer 28875, 21 Apr 1919 (BO); Zo. Saboentern 0.5 m, Backer 29746, 9 May 1919 (BO); Res Soeraharta [Surakarta $7^{\circ}$ 32' S 11050' E], zuidkust bij Paranggoepita c 20 m, Burger 5629, 31 Aug 1922 (BO). Kalimantan Barat: Karimata Arch., Poelau Pelapis Giangbalai, Mondi 136, 22 Mar 1931 (L, BO). Maluku: Ambon, Wae [Waa], Robinson 563, 29 Nov 1913 ([M], A, BM, BO, K, L, NSW, NY, P); Wae, Amboina [Ambon], Robinson s.n., Jul 1913 (NSW). Aru, Pulau Wokam, Dosinamaloe, Buwalda 4971, 16 May 1938 (BO, BRI); Lauterbach 259 (BO); Kobroor, Durbaum s.n., Aug 1995 (NSW); "Amboina", herb. Maire, leg. ign. (P); "Moluccas", Brogniart (BM). Buru, NW Wae Dana River $\mathrm{N}$ of Bara, 100-300 m, old river bed, limestone, LBN-L 5269, field no 208, 25 Nov 1984 (L). Halmahera, Pajehi [Payahe] Road, Weda District, de Haan 1798, 2 Nov 1950 (A, BO, K, L, NSW, NY, SING); Halmahera, cult. in kao town, Lindstrom 151 (NSW, UBC); road between Doro and Pediwang, on coral rock near sea, Lindstrom 153, 154 (NSW, UBC), Lindstrom 155 (UBC); on coral soil along stream near sea, Lindstrom 156-7 (NSW, UBC). Obi, Atasrip 60, 1899 (BO, L). Ternate, Sango, Beguin 1080, 1 Nov 1920 (BO); Takome, base of Mt Gamalama less than $50 \mathrm{~m}$ from sea, Lindstrom 158 (NSW, UBC); Sulamedaha, base of Mt Gamalama about $100 \mathrm{~m}$ from sea, Lindstrom 159 (NSW, UBC). Tidore, road between Sidangoli and Tobelo, between km 6 and 7, near roadside, Lindstrom 148 (NSW, UBC); Cult., in Kao town, Lindstrom 152 (NSW, UBC); near Bubaneigo, along road, Lindstrom 150 (NSW, UBC). Papua: Diak [? Biak ] Bosnik, Schouten Is., Gibbs 6278, Dec 1914 (K, BM). Sulawesi Utara: Menado, Loewoek, Tobelombang, Eyma 3727, 13-16 Sep 1938 (L, BO); Minahassa, Menado, strand, Pandano, Koorders \& Seepit 2868, 19 Feb 1895 (BO); Koorders 16646 (L ex BO); “specimen from Forster", Koorders 16647B (BO); Koorders 16648 (L, BO); Koorders 16648B, 19 Feb 1895 (B, K, L); N of Manado, Wori town, near beach, Lindstrom 145 (NSW, UBC); Sulawesi Tengah: N central, on coast SW of Donggala, Meijer 10071, 11 May 1975 (BO); Teijsmann s.n., 1859-60 (L). Sulawesi Selatan: Saleier group[?Salayar]: 2nd 
Saleier, zandige kust, van Leeuwin 1881, 13-16 Sep 1938 (BO); Saleier groep, Eil Kalao [Kalao Is], strand, van Leeuwin 1853, 2 May 1923 (BO); Tapalang, Noerkas 481, 4 Aug 1912 (K, L, BO). West Papua: Raja Ampat, Marchesa Bay Amdoei on N bank of bay, van Royen 3300, 2 Apr 1954 (L, BRI, CANB, K, P).

PAPUA NEW GUINEA: voyage of HMS Sulphur, Barclay 3540, Jul-Aug 1840 (BM, L); West Sepik: near Yakoi village, 1 mile [1.6 km] W of Aitape, Aitape Subdistrict, Darbyshire and Hoogland 7855, 3 June 1961 (CANB, BM, BRI, L, LAE); Yako village, Vanimo Subdistrict, Streimann LAE53828, 2 Dec. 1971 (LAE, BRI, K, L, CANB).

Cult. Royal Botanic Gardens, Sydney, Harwood s.n., May 1913 (NSW); Boorman s.n., 1902 (NSW); Boorman s.n., Jun 1915 (NSW); seed from Durbaum 1995, s.n. (NSW).

7. Cycas edentata de Laub., in de Laubenfels \& Adema, Blumea 43(2): 372 (1998).

Type: Philippines, Sulu Archipelago, Mt Cabucan, Kondo \& Edaño 38877, Jan-Feb 1957 (holo L, iso A, BM).

Cycas litoralis K.D. Hill, Brittonia 51(1): 70, fig. 11 (1999).

Type: Thailand. Ao Manao Naol, Narathiwat, K.D. Hill 4627 \& Poonsak Vatcharakorn, 20 Apr 1994 (holo NSW, iso BKF, K, L, PE)

Cycas circinalis subsp. riuminiana var. curranii forma maritima J. Schust., Pflanzenr. 99: 69 (1932).

Lectotype (here designated): Philippines, Calusa Island, 29 July 1912, Fenix 15660 (lecto K; isolecto L).

Literature: Lemaire (1864 as C. circinalis and C. rumphii), Kurz (1877 as C. rumphii), Foxworthy (1911 as C. circinalis), Merrill (1912 as C. circinalis), Merrill (1917 as C. rumphii), Merrill (1918 as C. circinalis), Merrill (1921 as C. circinalis), Merrill (1923 as C. rumphii), Backer (1925 as C. rumphii p.p.), Ridley (1925 as C. rumphii), Leandri (1931 as C. rumphii), Ochse (1931 as C. rumphii p.p.), Schuster (1932 as C. rumphii p.p.), Kanehira (1938 as C. rumphii p.p.), Ho and Duong (1960 as C. rumphii), Suvatabandhu (1961 as C. rumphii), Backer and Bakhuizen van den Brink (1963 as C. rumphii p.p.), Smitinand (1971 as C. rumphii), Smitinand (1972 as C. rumphii), Zamora and Co (1979 as C. circinalis), Amoroso (1986 as C. rumphii), Hill and Yang (1999 as C. litoralis).

Illustrations: Ridley (1925), Schuster (1932 as C. rumphii p.p.), Smitinand (1971), Cheng et al. (1975 as C. rumphii), Amoroso (1986 as C. rumphii), de Laubenfels and Adema (1998), Hill \& Yang (1999 as C. litoralis)

Etymology: from the Latin dentata, toothed, with the Latin prefix $e^{-}$, without, in reference to the megasporophyll apices.

Vernacular: kwale pahang (woods on sea shore)(Malay); prong thale (sea cycad) (Thai), sauang, sawang (Ilocano); bait, bayit, pitógo (preferred to potago, patubo, pitugo or bitogo) (Tagalog); oliba, oliva (preferred) (Spanish); uliba, uliva; (unidentified language) (Hill \& Vatcharakorn 1998, Ridley 1893, Amoroso 1986, Schuster 1932, Zamora \& Co 1986, Bonta \& Osborne 2007).

Stems arborescent, to $10 \mathrm{~m}$ tall, to $20 \mathrm{~cm}$ diam. at narrowest point. Leaves bright to deep green, highly glossy, 130-230 cm long, flat (not keeled) in section (opposing leaflets inserted at $180^{\circ}$ on rachis), with 100-200 leaflets, tomentum shedding as leaf expands; rachis consistently terminated by paired leaflets; petiole $30-90 \mathrm{~cm}$ long (20-50\% of total leaf), glabrous, spinescent for 5-100\% of length; basal leaflets not gradually reducing 
to spines, 120-280 mm long. Median leaflets simple, strongly discolorous, 220-370 mm long, 11-19 $\mathrm{mm}$ wide, inserted at $45-80^{\circ}$ to rachis, decurrent for 5-13 $\mathrm{mm}$, narrowed to $5-8 \mathrm{~mm}$ at base (to $35-50 \%$ of maximum width), $12-35 \mathrm{~mm}$ apart on rachis; section flat; margins slightly recurved, not undulate; apex acute, not spinescent; midrib flat or raised above, raised below, wide. Cataphylls narrowly triangular, soft, pilose, $40-70 \mathrm{~mm}$ long. Pollen cones narrowly ovoid or fusiform, orange, 35-60 cm long, 11-17 cm diam; microsporophyll lamina firm, not dorsiventrally thickened, 35-44 mm long, 12-23 mm wide, fertile zone 30-35 mm long, sterile apex 5-6 mm long; level to slightly deflexed; apical spine prominent, sharply upturned, 9-24 mm long. Megasporophylls 24-50 cm long, white-, yellow-tomentose or brown-tomentose, tomentum persistent; ovules 2-8, glabrous; lamina lanceolate, 43-120 mm long, 20-40 mm wide, lateral spines short or indistinct; apical spine distinct from lateral spines, $14-40 \mathrm{~mm}$ long, 4-12 mm wide at base. Seeds flattened-ovoid, 45-66 mm long, 35-50 mm wide; sarcotesta orange-brown, not pruinose, 3-5 mm thick; fibrous layer absent; sclerotesta smooth; spongy endotesta present. Fig. 4.

Historical notes: described by de Laubenfels and Adema in 1998. This taxon has been included in C. rumphii by numerous authors, starting with Kurtz (1877), with the exception of Foxworthy (1911), Merrill (1912, 1918, 1921) as C. circinalis, Schuster in 1932 described it as C. circinalis subsp. riuminiana var. curranii forma maritima. Hill recognised this as a distict taxon in 1995 (Hill 1998) and formally described the taxon as C. litoralis in April 1999. De Laubenfels had already described this taxon as C. edentata, published in 1998 but with a confused circumscription that included C. glauca, C. rumphii and others.

Distinguishing features: the non-pectinate megasporophyll (Fig. 4), the very glossy leaves and the large seed with spongy endotesta place this species unmistakably in the C. rumphii group. Within that group, it is distinguished from C. rumphii and all related species occurring to the south and east by the distinct, long, stout spines terminating the microsporophylls (Fig. 5.). C. thouarsii from the south-western Indian Ocean shares this microsporophyll character, but differs in having narrower leaflets that are distinctly glaucous when developing. C. zeylanica (J. Schust.) A.Lindstr. \& K.D.Hill from Sri Lanka and The Andamans is characterised by longer, narrower and more attenuate megasporophylls, more widely spaced leaflets and more abundant, longer and distinctly pungent cataphylls with a more rufous tomentum.

Distribution and habitat: Cycas edentata occurs in south Vietnam, southern Burma and southern Thailand, extending south into peninsular Malaysia, Sumatra, Java and northern Borneo but apparently not elsewhere in Indonesia (Fig. 1). Once common around the coast of southern Thailand, but now removed from many sites. It also occurs in the western and central parts of the Philippines. This species occurs only along shorelines, in full sun to moderate shade in often dry littoral scrubs on beach sand or rocky headlands, often in very shallow soil and apparently over both granite and limestone substrates.

Conservation status: once abundant and widespread, this species occurred in coastal sites that have experienced severe pressures from population increase and development. This habitat is also coming under increasing pressure for aquaculture sites. Although probably not immediately threatened, it is potentially vulnerable in the longer term. Recommended Ver 3.1:IUCN(2001) status would be NT for Indonesia. 
Selected specimens examined: INDONESIA: Bali: Gilimanuk, Forman 176, 9 Jun 1956 (BO, L). Jawa Barat: Oedjoeng Genteng [Ujunggenteng], Backer 17409, 25 Nov 1914 (BO); Pulau Panaitan, Tg Manik, beach, Borssum Waalkes 523, 13 Sep 1951 (L, BO); Pulau Handenberm [handeuleum], Uejong Kulor[Ujungkulon], W Java, Wyatt-Smith KEP 93185, 20 Dec 1958 (KEP, K); Cidaun distr., near Kabun Kopi village, on sand dune less than $50 \mathrm{~m}$ from sea, Lindstrom 166,170 (NSW, UBC); cult in village, coll. nearby, Lindstrom 171 (NSW, UBC); Pulau Handeulum, Udjong Kulou[n], W. java seashore, Wyatt-Smith KEP 93185, 20 Dec 1958 (KEP, K); Res W Preangar, Zuidkust, strand Oedjoeng Genteng bij pasanggrahan 1-2 m, van Steenis 11286, 29 Jun 1939 (BO). Jawa Tengah: Res Zuidkediri, Baai van Damas bij Prigi, 1 m, Backer 11956, 17 Feb 1914 (BO); Res. Preangar, Tjialin a/d Tjitarik, (by Tjisalak, Paroengkoeda) Res Oreabgar, 500 m, Bakhuizen v.d. Brink 5086, 21 Dec 1920 (BO); Wirosari dist, Cult Res Semarang Afd. Grobogan Ab Tambiredjo, Beaumee s.n., 25 Sep 1916 (BO); Pasveroean, Buysman 16, 14 Aug 1907 (BM); Java Tengah, Horsfeld 80 (BM, L); Banjumas, Nusa Kambangan Is., SW part betw. Solek Babakan and S. Djeroeh, Kostermans \& van Woerden 188, 23 Nov 1938 (BO, L); Jimghun, leg. ign. (L); Zuidelph deil van Paroela, leg. ign. 3825, 1912 (BO); Prov. Banjoemas, Noesa Kambangan, Koorders 20106 B, 10 Jun 1895 (L, BO); Noesa Kambangan, Barbey s.n., 23 Nov 1921 (L). Jawa Timur: bij Kamalbaai, Nusa Barung [c. $8^{\circ} 28^{\prime}$ S $113^{\circ} 21^{\prime}$ E], vern Soemberdjambe, Abdoelmachna 202, 12 Mar 1950 (BO); Res Bondowoa, Radjagwesiebaai, Barringtonia Bosch 0-3 m, Clason s.n., 6 Sep 1936 (BO); Res Mondooman, Radjegweribaai, Clason s.n., 6 Sep 1936 (BO); Res Besoeki, Noeesa Baroeng, Zuid Kandangan, Hoogerwerf 6, 4 Jul 1939 (BO); Besoeki [8 13' $\mathrm{S} 111^{\circ} 46^{\prime} \mathrm{E}$ ], Distr. Poeger afd. Djember, Boschterrein Poeger - Watangan [c.8 $8^{\circ} 05^{\prime} \mathrm{S} 112^{\circ} 55^{\prime}$ E], Koorders 12727 B, 10 Dec 1892 (L, BO). Sumatra:Unknown Province: Seemann 2329 (LE). Bengkulu: Enggano, Kiorjoh, Lutjeharms 4691, 13 Jun 1936 (BO, L, BRI, K, NY, P); Sumatra, Korthals 901324-28 (L); Batrie Eilanden, Raap 9, 3 Sep 1896 (BO, L); Benghoelen, Throei, van Steenis 3162, 25 Oct 1929 (L, BO). Lampung: Eile Krakatoa, Backer 50, 1910 (L); Backer 1918, Apr 1906 (B, K); Lang Eiland, Krakatau group, Backer 34865, 6 May 1908 (BO, L); Krakatoa, Lampangsche distr, Backer 34866, Apr 1906 (BO); Krakatau, Valeton s.n., 1 Mar 1905 (L); N Zirarte Hoeb, van Leeuwin 3721, 27 Apr 1919 (BO); N Zurarte Hoeb, van Leeuwin 3830, 6 Oct 1929 (BO). Riau: Anamba Islands, Padang near Leting Jemaya, Henderson SF 20338, 11 Apr 1928 (BO, K). Sumatra Utara: Cult., Sibolangit Bot. Gard., N. Sumatra "common in lowlands", Lorzing 12206, 20 Oct 1927 (BO, K); Medan, N. Sumatra, Lorzing 16881, 1934 (BO, L).

MALAYSIA: Johore: Tg Penawar, coast, Cockburn FRI 7565, 8 Feb 1968 (KEP, K); Pulau Tioman, Lee s.n., 28 May 1974 (BKF); Pulau Tinggi, rocky coast, Ng FRI 5034, 16 Apr 1967 (KEP); Mersing, Pulau Lima, rocky coast, Ng FRI 5062, 17 Apr 1967 (KEP); Desaru, Tg Penawar, Ng \& Yap FRI 27197, 25 Aug 1978 (KEP); Pahang Tanjong Gelang, beach forest, Putz FRI 023617, 27 Apr 1975 (KEP); SE, Padang Mulut, Shah \& Shukor MS 2480, 19 Sep 1971 (BKF, BRI); Desaru complex, beach forest, Yap FRI 27196, 23 Aug 1978 (KEP). Langkawi: P. Dayang Bunting, Henderson SING 29160, 27 Nov 1934 (K). Malacca: cult, Maingay 1506, 1867-68 (K). Pahang: Distr. Rompin, near Bevar village, road to Pekan, near edge of beach forest, Kochummans \& Yong KEP 9498, 30 Jul 1962 (KEP); Kwala Pahan, Ridley s.n., May 1890 (BM). Perak: Ridley 7143, Mar 1896 (K). Sabah: Membakut distr., HS Binsulok, Amin SAN 126098, 19 Jan 1991 (KEP); Kudat distr., Pulau Balembangan, midwest just E of Tg Penbatu, BCS, EFA, LM et al SAN 86813, 12 Apr 1977 (KEP, L); Mt Silamarea, Lahad Datu distr., Chai SAN 29392, 20 Apr 1962 (K ex SAN); Jesselton, Clemens 11277, Dec 1916 (B, K); Kota Kinabalu, Sapi Is 200 m W of Gaya Is, Davidson 1120, 9 Mar 1970 (L); Pulau Butang, leg. ign. 15699, Apr 1911 (K). Sarawak: Telok Limau, Bako NP, sandy sea shore, Ashton S 17927, 5 Jun 1963 (K); Santubong, 1st div., Chai et al. S 38561, 17 May 1980 (KEP, K, L); Kapit, upper Rejang River, J. \& M.S. Clemens 21175, 1929 (B, K, NY); Usatian Bay nr Keppel, Gibbs 4337, 1910 (BM); Datu PF, 1st div., Lee S 41866, 16 Apr 1977 (KEP, K, L); Kuching, Setapok FR, in peaty swamp forest near coast, c 100m, vern Paku laut, Murthy 9576, 1957 (K, L). Terengganu: Kemaman, Rasau Kerteh Ulu Chukai F.R., Hillside forest, Meijer \& F.C. Yong KEP 94932, 2 Jun 1962 (K); Pulau Redang, Pasir Mah Kepit, Saw FRI 36473, 4 Feb 1989 (KEP). 
PHILIPPINES: Balabac: Bancalan Is, Weber s.n., Jul 1916 (A). Basilan: Hutchinson FB 3441, 10 Dec 1905 (K); Klemme FB 15219, Aug 1910 (K, L).Cebu: Lapu Lapu City, Olango Island, Madulid et al. PPI 7623, 20 Mar 1993 (BO). Masbate: Hamoraon Island, Kondo \& Edano PNH 36862, 30 Mar 1957 (L). Mindanao: Davao Oriental, Mati district, Mayo Bay, cult. at the House of F.G.R.Dahican (Mayor), Planted 1960's, said to come from nearby now destroyed seaside, Lindstrom 06/001, 06/002, 29 Feb 2006 (NSW); Prov. Davao, Caldera, Wilkes exped. s.n., 18321842 (GRAY); Santa Cruz, Williams 2890, 17 Jun 1905 (NY); between Digas and Santa Cruz, Williams 3058, 29 Jun 1905 (GRAY, K, NY). Mindoro: Bongabon and Pinamalayan, Maliwanag 253, 5 Feb-5 Apr 1941 (A). Negros: Negros Oriental, Dumaguete district, Secondary seriously destroyed seaside forest, Lindstrom 06/005, 3 Mar 2006 (NSW). Palawan: Culion, Alava Island, Halsey Harbour, Fernando E 1609, 1610, 22 Jun 2001 (LBC); cult. Puerto Princessa city, coll. from coastal forest near San Vicente, Fernando E 1616, 26 Jun 2001 (LBC). Panay: Iloilo, fide Amoroso 1986 (no voucher). Polillo: fide Amoroso 1986 (no voucher).

SINGAPORE: Changi, Ridley 4408, 1892 (BM, K); Ridley s.n., 1893 (BM, K); Kampong Pesek, Pulau Pesek, Sinclair 5842, 6 Jun 1949 (E).

THAILAND: "Pulau Mohea, WC Siam" vern. Bogak, Field 2690, 2 Feb 19[??] (K). Chumphon: collected from Chumphon, cult. Nong Nooch Garden, Hill 4644, 30 Apr 1994 (NSW); Ban Thung Maha, Kerr 11355, 11355A, 10 Jan 1927 (BM, K); Ko Tao, Kerr 12768, 16 Apr 1927 (BM, K); Kerr 16087, 25 Sep 1928 (BM, K). Narathiwat: Narathiwat, Charoenphol, Larsen \& Warncke 4064, 20 Oct 1970 (BKF, K, P); Ao Manao Nowl, Narathiwat, Hill 4627, 20 Apr 1994 (NSW); near Narathiwat, Yang 632, Tang \& Vatcharakorn, 27 Jan 1995 (FTG). Phang Nga: Takuapa, Abbe, Smitinand \& Rollet 9684, 19 Mar 1960 (NY); Ko Ngai, Hansen \& Smitinand 12242, 11 Feb 1966 (BKF, E, K); Ko Kaw Khao, Larsen, Larsen, Neilsen \& Santisuk 30984, 15 Jul 1972 (BKF, P); Phu Ket: cult. Ban Na Si Thon, collected from Phuket, Hill 4630, 21 Apr 1994 (NSW); cult. Nong Nooch Garden, Yang 659, Tang \& Vatcharakorn, 30 Jan 1995 (FTG). Satun: Adang, beach, Congdon 101, 23 Oct 1979 (A); Tarutas, across Malacca Ck, Congdon 42, 17 Oct 1979 (A). Trang: "Pulau Mohea, WC Siam", vern. Bogak, Field 2690, 2 Feb 19[??] (K); island off coast near Trang, Robinson s.n., Dec 1916 (K). Trat: Ko Chang, Kerr 16569, 10 Jan 1929 (BM, K); Ko Kut, Smitinand 5725, 6 Apr 1959 (BKF).

VIETNAM: Kien Giang: near beach, west part of Phu Quoc island, leg. ign. (Botany Dept Univ Ho Chi Minh).

Cult.: hort Bogor, Indonesia, Stolk 149 (BO, L).

\section{Cycas sundaica Miq. ex A.Lindstr. \& K.D.Hill, sp. nov.}

A Cycade rumphii et C. edentata megasporophyllis spinis lateralibus prominentibus, foliolis plerumque angustioribus differt.

Type: Flores, Ngada province, foot of Volcano Inerie, along the Eku Ture river, mear Bidhu village, 326 m ASL, Lindstrom 255, 29 Apr 2000 (holotype: BO, iso: UBC).

[Cycas sundaica Miq. in J.Schust., Pflanzenr. 99: 74 (1932), nom. nud. in synonymy]

Etymology: from the habitat, entirely within the Sunda Island group.

Stems arborescent, to $5 \mathrm{~m}$. tall, 20-35 cm. diam. at narrowest point. Leaves bright green or deep green, 120-275 cm long, flat in section (opposing leaflets inserted at $180^{\circ}$ on rachis), with 75-114 leaflets, with orange to greyish tomentum shedding as leaf expands; rachis usually terminated by a spine to $13 \mathrm{~mm}$ long; petiole $30-67 \mathrm{~cm}$ long (20-40\% of total leaf), spinescent for $10-100 \%$ of length; basal leaflets not gradually reducing to spines. Median leaflets simple, strongly discolorous, 230-340 mm long, 9-15 mm 
wide, narrowed to 3-5 $\mathrm{mm}$ at base (25-50\% of maximum width), 13-23 mm apart on rachis; section flat; margins slightly recurved; apex spinescent; midrib flat above, raised below. Cataphylls linear, pungent, to $10 \mathrm{~cm}$ long. Pollen cones ovoid, c. 16-30 cm long, 9-15 cm wide; microsporophylls firm, not dorsiventrally thickened, 30-55 mm long, 15-29 mm wide, fertile zone 22-45 mm long, sterile apex 6-10 $\mathrm{mm}$ long, apical spine abruptly raised, 12-20 mm long. Megasporophylls 30-42 cm long, tomentum persistent; ovules 2-8, glabrous; lamina lanceolate, 30-80 mm long, 20-43 mm wide, shallowly pectinate or regularly dentate, with 4-30 pungent lateral spines $1-12 \mathrm{~mm}$ long, $1-1.5 \mathrm{~mm}$

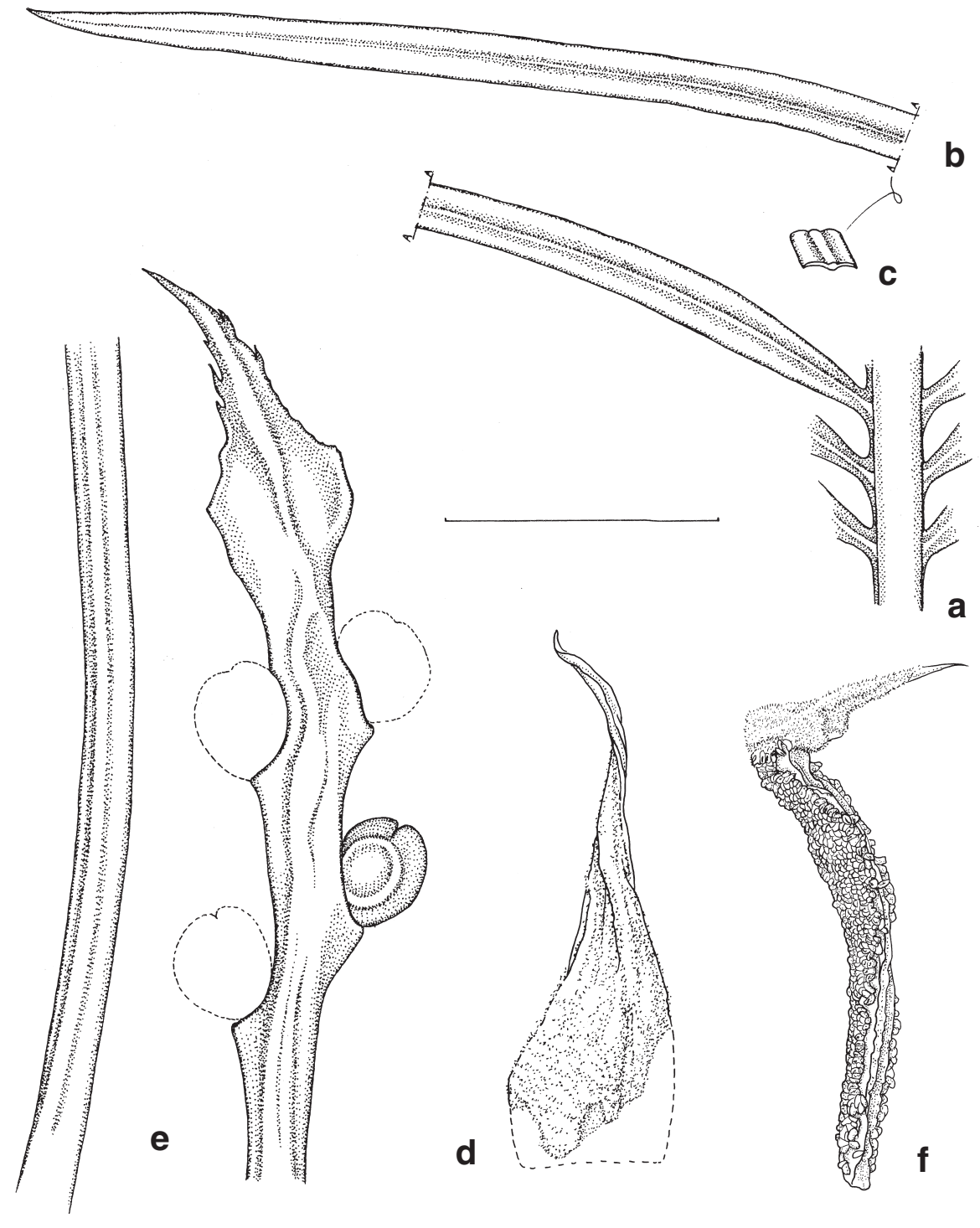

Fig. 6. Cycas sundaica. a, b, part of leaf. c, cross-section of leaflet. d, cataphyll. e, female sporophyll. f, male sporophyll (a, b, c, d, e from Lindstrom 255, f from Lindstrom 258. d, f, by C. Wardrop). Scale bar: $\mathrm{a}-\mathrm{e}=5 \mathrm{~cm} ; \mathrm{f}=2.5 \mathrm{~cm}$. 
wide; apical spine distinct from lateral spines, $30-50 \mathrm{~cm}$ long, 3-7 mm wide at base. Seeds ovoid, 45-55 mm long, 35-45 cm wide, sarcotesta orange, c. $8 \mathrm{~mm}$ thick, fibrous layer absent; sclerotesta smooth; spongy endotesta present. Fig. 6.

Historical Notes: $C$. sundaica was a name used by Miquel on a herbarium sheet in Utrecht. Schuster (1932) listed Miquel's name in synonomy under C. rumphii, although Miquel never published the name.

Distinguishing features: the distinct lateral spines on the megasporophyll lamina distinguish this taxon from the nearby and related C. rumphii and C. edentata. Leaflets are also on average narrower.

Distribution and habitat: Nusa Tenggara Timur only, on Sumbawa, Komodo, Rinca, and Flores, east to Alor, in near-coastal and lowland forests (Fig. 1).

Conservation status: locally abundant and known to occur in reserved areas set aside for the conservation of the Komodo Dragon, this species is not considered to be at immediate risk. Recommended Ver 3.1:IUCN(2001) status would be LC.

Selected specimens examined: INDONESIA: Nusa Tenggara Timur: Alor, Altimelang, $750 \mathrm{~m}$, du Bois 74, 26 Jan 1939 (BO); Distr. Krei, Moro-Gendok, 300 m, Jaag 667, 7 May 1938 (BM); Taramana, Pisigomo 700 m, Jaag 893, 11 May 1938 (BM); Flores, Endeh, 20 m, Rensch 982, 9 Jun 1927 (BO); W. Flores, E. Manggarae, Pota, 200 m, Schmutz 4712, Dec 1980 (L); Ngada province, foot of Volcano Inerie, along the Eku Ture river, mear Bidhu village, Lindstrom, 256, 259, 29 Apr 2000 (BO, UBC).

Subsection Endemicae Schuster (1932: 65).

Lectotype (here designated): Cycas media R.Br. Prodr. 1: 348 (1810). Type: Australia, "New Holland, North Coast", R. Brown s.n. (holo BM; iso K).

No type species was designated. Schuster included three species in this section, which he defined only on the pungent-acuminate pinnae and the relatively small and slender megasporophylls. Cycas media R.Br. is chosen as lectotype of the subsection, being the most well-known and earliest-described of the three species, and also adequately satisfying Schuster's definition.

This subsection is distinguished by the relatively flattened microsporophylls with a short and sharply upturned apical spine, the lack of spongy tissue within the seed, and the lack of a fibrous layer in the sarcotesta. Pinnae are often pungent-acuminate, as stated by Schuster, but not in all species, and often no more so than in other groups. Eight series are recognised (Hill 1995b), six of them endemic in Australia, and two occurring in Australia and New Guinea. About 26 species are endemic in Australia, two endemic in Papua New Guinea, one species ocurring in Papua New Guinea and Irian Jaya, and one on Timor and Sumbawa.

9. Cycas glauca hort. ex Miq., Comm. Phytog.: 127 (1840-1841), non Link, Enum. Hort. Berol. Alt. (1821-22), nom. nud., nec Sweet, Hort. Brit. ed. 3: 627 (1839), nom. nud. Cycas circinalis forma glauca (Miq.) J. Schust., Pflanzenr. 99: 66 (1932).

Lectotype (here designated): Hort. Roterodam. (lecto U). This sheet most closely matches the basally restricted leaflets later described by Miquel (1868).

Cycas rumphii var. timorensis Miq., Comm. Phytolog.: 125-126 (1840-1841).

Type: Indonesia, Timor, ex Herb. Mus. Paris (holo L; iso LE, U). 
Literature: Miquel (1842, 1843, 1861, 1868,), Lemaire (1864), De Candolle (1868), Regel (1876a, 1876b), Hill (1995a), Hill (1998), de Laubenfels and Adema (1998).

Etymology: from the Greek, glaucus, with a bluish waxy bloom, in reference to the bluish glaucous leaves.

Vernacular: fay (Amarassi dialect, West Timor).

Stems arborescent, to $3 \mathrm{~m}$ tall, 22-35 $\mathrm{cm}$ diam. at narrowest point, normally unbranched but occasionally branching 2-4 times at the apex. Leaves dark green, semi glossy, with a distinct glaucous blue cast, 174-220 cm long, flat (not keeled) in section (opposing leaflets inserted at $180^{\circ}$ on rachis), with $69-118$ pinnae, tomentum often present even on mature leaves; petiole $42-58 \mathrm{~cm}$ long (20-40\% of total length), covered in short orange tomentum, glaucous, spinescent for 20-100\% of its length. Median leaflets simple, glabrous, moderately discolorous, $15-30 \mathrm{~cm}$ long, 12-16 mm wide, narrowed to $0.2-0.5 \mathrm{~cm}$ at base (25-35\% of total width), 5-14 $\mathrm{mm}$ apart on rachis, section flat, margins recurved, midrib slightly raised above, strongly raised below. Cataphylls narrow, elongated, soft, 3-4 cm long. Pollen cones c. $49 \mathrm{~cm}$ long, c. $10 \mathrm{~cm}$ wide, brownish, peduncle $8 \mathrm{~cm}$ long; microsporophyll 38-40 mm long, 18-20 mm wide, fertile zone 28-30 mm long, sterile apex c. $10 \mathrm{~mm}$ long, apical spine to $20 \mathrm{~mm}$, raised. Megasporophylls 30-43 cm long, with persistent orange-brown tomentum; ovules 4-7, glabrous; lamina 25-40 mm long, 23-35 mm wide, shortly pectinate or with rudimentary spines; apical spine distinctfrom lateral spines, 20-40 mm long, 2-5 mm wide. Seeds flattened, 4-5 cm long, to $3 \mathrm{~cm}$ wide, sarcotesta yellow, ripening to dark brown red, strongly pruinose; fibrous layer absent, sclerotesta weakly ornamented; spongy layer absent. Fig. 7.

Historical notes: described by Miquel in 1840-41 from cultivated material in European collections as C. glauca. He also described C. rumphii var. timorensis in the same publication from a herbarium specimen in the Paris museum. Miquel in 1861 listed C. glauca under 'species incertae' and in 1868 under 'nondum satis certae' (not yet sufficiently certain). Lemaire in 1864 followed Miquel listing C. glauca under doubtful species. De Candolle (1868) listed C. glauca under 'species minus notae' and Regel (1876) treated it as C. glauca. Schuster (1932) regarded C. glauca as a variety of C. circinalis, without really understanding the nature of C. glauca.

The types of Cycas glauca and C. rumphii var. timorensis consist solely of sterile leaves, making it extremely hard to relate it to any previously described species. Hill (1995a) first placed C. glauca into synonymy with C. rumphii but later (Hill 1998) placed the taxon into synonymy with $C$. thouarsii. De Laubenfels (1998) unaware of the type in Utrecht, regarded C. glauca as a nomen nudum but placed C. glauca into synonymy with $C$. rumphii and C. rumphii var. timorensis into the synonymy of his newly described C. edentata. More recent fieldwork conducted in Indonesia as part of an ongoing study into the systematics of the genus Cycas has shown C. glauca to be a distinct taxon unrelated to the C. rumphii group, widespread and locally abundant on the islands of Sumba and Timor.

Distinguishing characters: Cycas glauca is related to the Australian species, probably nearest to $C$. silvestris on the basis of leaflet width but differs in the distinct glaucous blue cast on the emerging leaves. It has a superficial resemblance with and could be confused with $C$. thouarsii (Indian Ocean) due to the bluish cast on the leaves, but differs in having wider pinnae and smaller seeds lacking a spongy layer. 


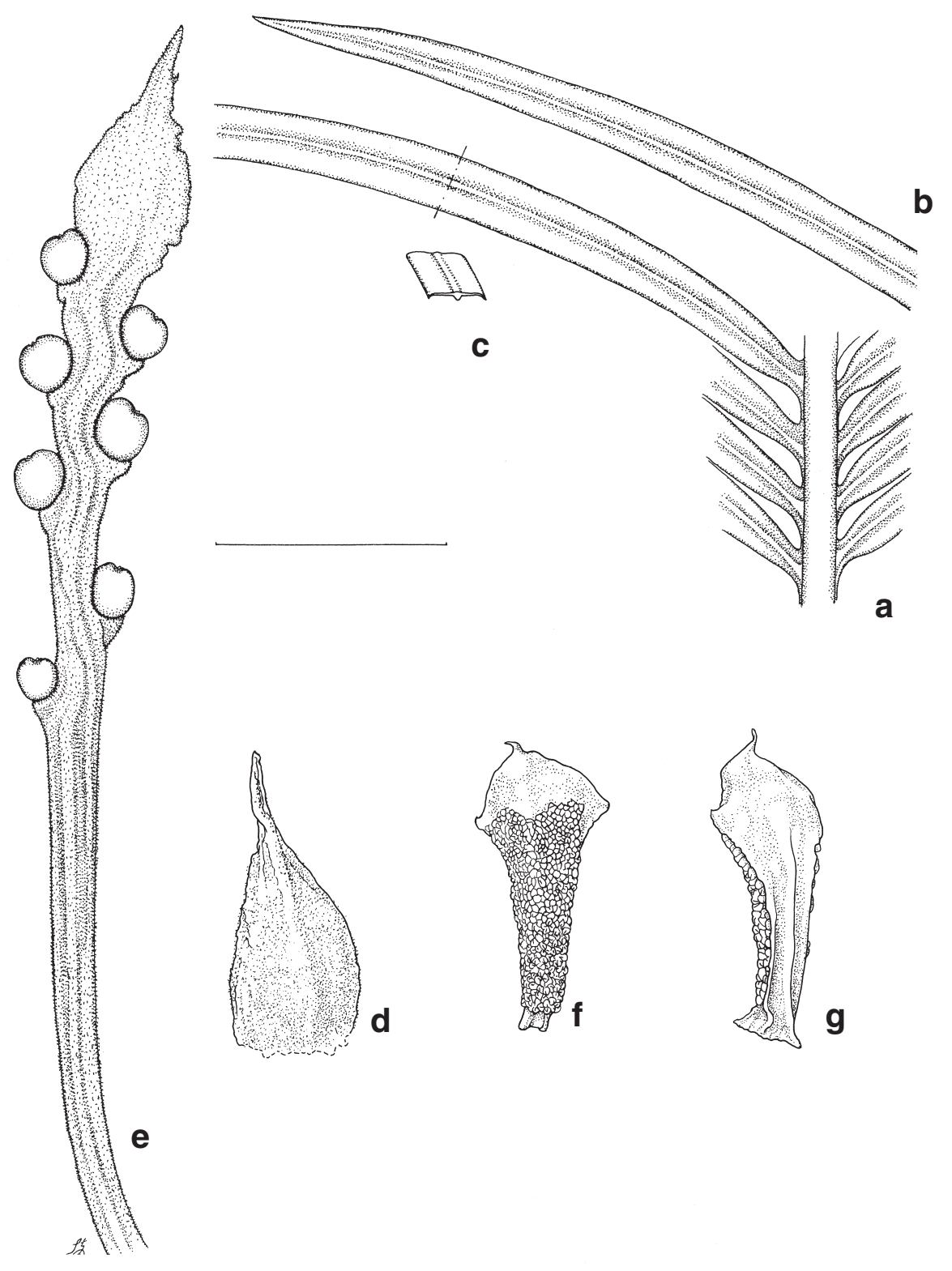

Fig. 7. Cycas glauca. a, b, part of leaf. c, cross-section of leaflet. d, cataphyll. e, female sporophyll. f, g, male sporophyll (a, b, c, d, e from Lindstrom 274. f, g from digital image (NSW) from Lindstrom, cult. Nong Nooch Botanic Gardens. d, f, g by C. Wardrop). Scale bar: a-e $=5 \mathrm{~cm}$; $\mathrm{f}, \mathrm{g}=2.5 \mathrm{~cm}$ 
Distribution and Habitat: Cycas glauca is apparently endemic to the islands of Timor and Sumba (Fig.1). Populations occur in closed evergreen forest, inland, often near streams. Populations also persist in disturbed areas.

Conservation Status: Cycas glauca is apparently quite widespread and locally abundant on both Sumba and Timor. It is unknown if there are any populations within protected areas. The present political unrest in Indonesia and Timor in particular, give cause for concern, as effective protective measures would be difficult to implement. Recommended Ver 3.1:IUCN(2001) status would be VU.

Selected specimens examined: INDONESIA: Nusa Tenggara Timur: Sumba: Exped. Soemba [Sumba], Djore, [Iboet] 237, 11 Apr 1925 (BO, B, L); Sumba Timur: near Paimburu village, 274 m ASL, in sparse open evergreen forest, seasonally dry, clay soil, Lindstrom 267, 268, 4 May 2000 (BO, UBC); Sumba Barat: northern part, near Tana Righu village, Lindstrom 273, 6 May 2000 (BO, UBC); Cult. Waingapu town (Sumba Timur), Lindstrom 274, 6 May 2000 (BO, UBC). Timur Barat: 'Kabupaten Kupang, Amarassi prov' near Oekabiti village, in closed evergreen forest Lindstrom 245, 25 Mar 2000 (BO, UBC); East Amarassi prov. near Baun village, $415 \mathrm{~m}$ ASL, Lindstrom 246, 25 Mar 2000 (BO, UBC).

TIMOR: Leschenault s.n. (P); ex herb Moricand, 1827 (P, G).

10. Cycas papuana F.Muell., Descr. Notes Papuan Pl. 1,4: 71-72 (1876). Cycas circinalis subsp. papuana (F.Muell.) J. Schust., Pflanzenr. 99: 70 (1932). Cycas rumphii forma papuana (F.Muell.) Kaneh., J. Jap. Bot. 14(9): 587 (1938).

Lectotype (fide Hill 1994b): Papua New Guinea, Western, Fly River, D’Albertis s.n. (lecto MEL 68056 (photo NSW); isolecto K).

Literature: Beccari (1877 as C. rumphii), Lauterbach (1900 as C. circinalis in part), Hill (1994b).

Illustrations: Schuster (1932 as C. circinalis subsp. papuana, figs 10J and 11H), Hill (1994b, fig. 5).

Etymology: from its original collection from the British Territory of Papua.

Vernacular: Warnara (Unident language) (Bailey 1909, Bonta \& Osborne 2007).

Stems arborescent, to $2.8 \mathrm{~m}$ tall. Leaves bright green (bluish when new), semiglossy, $100-130 \mathrm{~cm}$ long, slightly keeled (opposing pinnae inserted at $130-160^{\circ}$ on rachis), with 180-250 leaflets, with white and orange tomentum shedding as leaf expands; rachis usually terminated by a spine; petiole $30-40 \mathrm{~cm}$ long (25-35\% of total leaf), glabrous, unarmed; basal leaflets not gradually reducing to spines, 30-90 mm long. Median leaflets simple, weakly discolorous, $80-130 \mathrm{~mm}$ long, 6-9 $\mathrm{mm}$ wide, inserted at $60-80^{\circ}$ to rachis, decurrent for $1.5-5 \mathrm{~mm}$, narrowed to $3.5-5.5 \mathrm{~mm}$ at base (to $55-$ $65 \%$ of maximum width), 5.5-14 mm apart on rachis; section flat; margins flat; apex acute, not spinescent; midrib raised above, raised below. Cataphylls linear, pungent, pilose, densely orange-tomentose. Pollen cones ovoid, orange, $15-20 \mathrm{~cm}$ long, $810 \mathrm{~cm}$ diam.; microsporophyll lamina firm, not dorsiventrally thickened, c. $24 \mathrm{~mm}$ long, c. $10 \mathrm{~mm}$ wide, fertile zone c. $17 \mathrm{~mm}$ long, sterile apex c. $7 \mathrm{~mm}$ long, level, apical spine rudimentary, sharply upturned, 1-5 mm long. Megasporophylls 16-20 cm long, browntomentose; ovules 2-6, glabrous; lamina lanceolate, 35-50 mm long, 17-25 mm wide, regularly dentate with 14-20 pungent lateral spines, 2-4 mm long; apical spine distinct from lateral spines, $8-15 \mathrm{~mm}$ long. Seeds flattened to ovoid, 32-35 $\mathrm{mm}$ long, $25-29 \mathrm{~mm}$ 
wide; sarcotesta orange-brown, not pruinose, 1.5-2.5 mm thick; fibrous layer absent; sclerotesta smooth; spongy endotesta absent.

Historical notes: the basis of this species was cited only as 'On the Fly-River; D'Albertis. The two sheets MEL68056 and MEL68057 (photos NSW) apparently collected by D’Albertis were annotated only by Mueller, and do not bear D'Albertis' name. A portion of the former was sent to $\mathrm{K}$ by Mueller, according to his annotation on the sheet. The sheet MEL68056, annotated by Mueller 'parofolii supera / Fly-River', is more comprehensive, and has been designated the lectotype.

Distinguishing features: Cycas papuana is nearest to C. armstrongii Miq., differing in the longer leaves with longer petioles and more leaflets (C. armstrongii has leaves 55-90 cm long with petioles 10-25 long and 160-220 leaflets). The long, unarmed petiole resembles that of $C$. conferta Chirgwin \&Wigston, which differs in the somewhat shorter leaves (70-110 cm long) with more closely crowded leaflets (spaced at $4.0-7.0 \mathrm{~mm}$ on rachis), less extended sterile apex on the microsporophylls $(6-8 \mathrm{~mm}$ long), and larger seeds (36-40 mm long). Both C. armstrongii and C. conferta are endemic in the Northern Territory of Australia.

Distribution and habitat: Papua New Guinea, Western District, from the flood-plains of the Fly River and around Daru west at least to the Bensbach River. A sporadic but widespread component of savanna woodlands on flat country, sometimes locally abundant. Also present across the border in Indonesian territory (Wasur National Park). Fig. 1.

Conservation status: abundant and apparently not at risk. Although in a national park in Indonesia, there is significant land use pressure in this area, and conservation is somewhat in doubt in this region. Ver 3.1:IUCN (2001) status is NT (Donaldson 2003) for Indonesia and PNG.

Selected specimens examined: INDONESIA: Papua: Merauke, Tanah Miring, 10 November 2002, Hambali, Gregory s.n. (NSW).

PAPUA NEW GUINEA: Western: Mabaduan, Brass 6541, Apr 1936 ([A], BRI, LAE); Mausa, c. $15 \mathrm{~km}$ W of Morehead, on Morehead to Weam road, Conn 3523 \& Jacobs, 26 Sep 1990 (NSW, LAE); Sibidiri, Morehead Subdistrict, Foreman et al. LAE60493, 22 Jul 1974 (LAE, BRI, CANB, A[n.v.], K, L, QRS [n.v.]); 2 km W of Ioka, Daru Subdistrict, Foreman et al. LAE60454, 19 July 1974 (LAE, CANB, A [n.v.], L, QRS [n.v.]); Mabaduan Hill, Daru Subdistrict, Foreman \& Stocker LAE59094, 24 Jul 1974(LAE, BRI, CANB, A [n.v.], BRI [n.v.], L, QRS [n.v.]); 1 km N of Buji, mouth of Mai Kussa River, Harris 138, 9 Nov 1974 (DNA); next to Bensbach Wildlife Reserve office, Rau UPNG6800, 7 Dec 1982 (LAE, DNA, MEL [n.v.]).

\section{Excluded names}

Cycas rumphii var. subinclusa Schuster., Pflanzenr. 99:75 (1932).

Type: the illustration, Schuster, Pflanzenr. 99:75 Fig. 12 Y-Z (1932)

The type drawing appears to have been made from dried material of a plant cultivated at the Botanical garden in Utrecht. The epithet refers to the way the ovules are held on the megasporophyll. However this character appears to be an artifact of the drying process. This drawing lacks the megasporophyll lamina, which is crucial for correct identification. Schuster clearly states 'Laminae macrosporophyllii profunde pinnatifidae'. Judging by Schuster's confused concept of C. rumphii and the statement 
of a "very pinnatifid megasporophyll lamina", this name should not be further associated with C. rumphii. Without a complete megasporophyll lamina it will forever be impossible to correctly identify this taxon. No herbarium specimens are known to exist that can be related to this description or the cultivated plant. The cultivated plant can no longer be located.

Cycas corsoniana G.Don, Gard. Mag. \& Reg. Rural Domest. Improv. 18: 371 (1842); name only, in syn. (Schuster 1932). Zamia corsoniana G. Don, Gard. Mag. \& Reg. Rural Domest. Improv. 18: 371 (1842); name only.

Cycas corsoniana G.Don was one of four newly described taxa discovered by Mr. James Corson during his trip to the "South Seas". The locality was said to be Batagoda and (!) Geby. It has not been possible to trace these localities even to country of origin. The description states "scales of strobile cuneated, each with an incurved hook at top, on the upper face". The mention of the spinose tip on the microsporophyll, which is so long that it is curved is interesting as C. rumphii has no, or only a rudimentary spinose tip on the microsporophyll. This name should not be associated with C. rumphii, although it may be matched with another taxon in the Rumphiae subsection. The type specimen has not yet been located and does not exist in the Linnean Society Herbarium but may be in the herbarium of the late Professor Don. The Don collection was auctioned to the Natural History Museum of London (Lot no. 254) in the sale of $10^{\text {th }}$ November 1863.

\section{Acknowledgments}

Mr. Kampon Tansacha the owner and Director of Nong Nooch Tropical Botanical Garden, Thailand is most gratefully acknowledged for his relentless encouragement and full sponsorship of the field trips. The Slade Foundation of Sydney is also thanked for assistance with travel and field studies. The staff of the Royal Botanic Gardens, Sydney, have been of invaluable assistance, and this would not have been published without them, in particular Peter Wilson is thanked for assistance with Latin and Catherine Wardrop for additional illustrations. Illustrations are by Stig Dalstrom except where stated. We would also like to thank Dr. Irawati and Dr. Kartini at the Bogor Herbarium, Indonesia, for assistance, access to the herbarium and invaluable help. Mr. G. Hambali, Indonesia, is gratefully for assistance and invaluable help in the field. Dr. D.J. De Laubenfels, Syracuse University, U.S.A. is thanked for suggestions and advice.

\section{References}

Amoroso VB (1986) Morphological study of the sporophylls of Philippine Cycas. Philippine Journal of Science 115(3): 177-198.

Backer CA \& Bakhuizen van den Brink RC (1963) Cycadaceae. P. 87 in Flora of Java, vol. 1. (Noordhoff: Gronongen)

Backer CA (1925) Handboek voor de Flora van Java. Pt 1 (Ruygrock \& Co.: Batavia)

Bailey FM (1909). Contribution to flora of British New Guinea. Queensland Agricultural Journal 22(3):147-150.

Beccari O (1877) Malesia, vol.1. p178 (R. Instituto Sordo-Muti: Genova)

Blume KL (1848) Rumphia, Sive Commentationes Botanicae, vol. 4: 11-18.

Bonta M \& Osborne R (2007) Cycads in the Vernacular in Proceedings of the Seventh International Conference on Cycad Biology. Memoirs of New York Botanical Garden Vol. 97. 
Borell GW (1989) An Annotated Checklist of the Flora of Kairiru Island, New Guinea. (G.W. Borell, Marcelin College, Victoria)

Cheng WC, Fu LK \& Cheng CY (1975) Gymnospermae Sinicae. Acta Phytotaonomica Sinica 13(4): 81-82.

De Candolle AP (1868) Cycadaceae. Pp. 522-548 in de Candolle AP (ed.) Prodromus Systematis Naturalis Regni Vegetabilis 16(2). (Masson: Paris)

De Laubenfels DJ \& Adema F (1998) Revision of the genera Cycas and Epicycas gen.nov. (Cycadaceae). Blumea 43(2): 351-400.

Dehgan B \& Yuen CKH (1983) Seed morphology in relation to dispersal, evolution and propagation of Cycas. Botanical Gazette 144(3): 412-418.

Don D (1840) On the structure of the tissues of Cycadaceae. Proceedings of the Linnean Society of London 1: 53-56.

Donaldson J S (ed.) (2003) Cycads. Status Survey and Conservation Action Plan. IUCN/SSC Cycad Specialist Group (IUCN: Gland and Cambridge)

Duyster M (1927) Giftige indische planten en plantenbestanddeelen. (Bandoeng: Visser \& Co.)

Fosberg FR \& Sachet M-H (1975) Flora of Micronesia, 1: Gymnospermae. Smithsonian Contributions to Botany 20: 1-15.

Foxworthy FW (1911) Philippine gymnosperms. The Philippine Journal of Science 6(3): 149-152.

Hill KD (1994a) The Cycas rumphii complex (Cycadaceae) in New Guinea and the Western Pacific. Australian Systematic Botany 7: 543-567.

Hill KD (1994b) The Cycas media group (Cycadaceae) in New Guinea. Australian Systematic Botany 7: 527-541.

Hill KD (1995a) The genus Cycas (Cycadaceae) in the Indian region, with notes on the application and typification of the name Cycas circinalis L. Taxon 44: 23-31.

Hill KD (1995b) Infrageneric relationships, phylogeny, and biogeography of the genus Cycas (Cycadaceae). Pp 139-162 in Vorster P(ed.) Proceedings of the Third International Conference on Cycad Biology. (Cycad Society of South Africa, Stellenbosch)

Hill KD (1998) The Cycad Pages, Royal Botanic Gardens Sydney. http://plantnet.rbgsyd.nsw. gov.au/PlantNet/cycad/index.html

Hill KD \& Vatcharakorn P (1998) The Cycads of Thailand. Pp. 178-190 in Hodel DR (ed.) The Palms and Cycads of Thailand. (Kampon Tansacha, Nong Nooch Tropical Garden: Thailand)

Hill KD (2004a) Character evolution, species recognition and classification concepts in the Cycadaceae. Pp. 23-44 in Walters T \& Osborne R (eds) Cycad classification concepts and recommendations. (CABI Publishing: Wallingford)

Hill KD (2004b) An analysis of morphological characters used in classification of the Cycadaceae. Pp 6-29 in Lindstrom AJ (ed.) The Biology, Structure \& Systematics of the Cycadales Proceedings of the Sixth International Conference on Cycad Biology, Thailand, 29 July-3 Aug, 2002. (The Nong Nooch Tropical Botanical Garden: Sattahip)

Hill KD (2008) The genus Cycas (Cycadaceae) in China. Telopea 12(1):71-118.

Hill KD \& Yang, S-L(1999) The Genus Cycas (Cycadaceae) in Thailand. Brittonia 51(1): 48-73.

Ho P \& Duong N (1960) Cay-co mien nam Viet-nam. (Ministry of National Education: Saigon)

Howard FW, Hamon A, McLaughlin M \& Weissling T (1999) Aulacaspis yasumatsui (Homoptera: Sternorrhyncha: Diaspididae), a scale insect pest of cycads recently introduced to Florida. Florida Entomolgist 82: 14-27.

IUCN (2001) IUCN Red List Categories and Criteria: Version 3.1. IUCN Species Survival Commission. IUCN, Gland, Switzerland and Cambridge, UK.

IUCN Cycad Specialist Group (2006). Subgroup on Invasive Pests. Report and Recommendations on Cycad Aulacaspis Scale, Aulacaspis yasumatsui Takagi (Hemiptera: Diaspididae). Updated 17 January 2006. http://cycadsg.org/publications/CAS/CSG-Report-on-Cycad-AulacaspisScale.pdf

Jarvis CE, Barrie FR, Allan DM and Reveal JL (1993) A list of Linnaean generic names and their types. Regnum Vegetabile 127, 1-100.

Jones DL (1993) Cycads of the World. (Reed: Chatswood) 
Jones DL (2002) Cycads of the World, 2nd ed. (Reed New Holland: Sydney)

Kanehira R (1938) On the Micronesian species of Cycas. Journal of Japanese Botany 14: 579-588.

Koorders SH (1911) Exkursionsflora von Java. (Fischer: Jena)

Koorders SH (1913) Exkursionsflora von Java: Atlas. (Batavia)

Kurz S (1877) Forest flora of British Burma, vol 2. (Govt. Printer: Calcutta)

Lauterbach K (1900) Cycadaceae. Pp.153-155 in Die Flora der deutschen Schutzgebeite in der Sudsee (K. Schumann \& K. Lauterbach: Borntraeger, Leipzig)

Leandri J (1931) Cycadaceae. Pp. 1085-1092 in Lecomte MH \& Gagnepain F (eds) Flore Generale de L'Indo-Chine, vol. 5. (Masson et Cie: Paris)

Lemaire C (1864) L'Illustration Horticole, vol XI. (F \& E Gyselynck: Gand)

Lindstrom JA (2002) Circumscription and lectotypification of Cycas rumphii (Cycadaceae). Brittonia 54(4): 305-309.

Lindstrom AJ \& Hill KD (2007) The genus Cycas (Cycadaceae) in India. Telopea 11(4): 463-488.

Lindstrom AL, Hill KD \& Stanberg LC (2008) The genus Cycas (Cycadaceae) in The Philippines. Telopea 12(1):119-145.

Linnaeus C (1753) Species Plantarum, vol. 1. (1960 facsimile edn. H.R. Engelmann: Weinheim)

Linnaeus C (1754) Genera Plantarum. Edn 5. (1934 facsimile edn. Shokobutu Bunken: Tokyo)

Merrill ED (1912) A Flora of Manilla. (Bureau of Science: Manila)

Merrill ED (1917) An Interpretation of Rumphius's Herbarium Amboinense. (Bureau of Science: Manila)

Merrill ED (1918) Species Blancoanae. (Bureau of Science: Manila)

Merrill ED (1921) A Bibliographic Enumeration of Bornean Plants. Journal of the Straits Branch of the Royal Asiatic Society, Straits, Special No. (Fraser \& Neave: Singapore)

Merrill ED (1923) An Enumeration of Philippine Flowering Plants, vol. 1. (Bureau of Science: Manila)

Miquel FAW (1839) Melanges botaniques. Bulletin des Sciences Physiques et Naturelles en Neerlande 2: 36, 44-46.

Miquel FAW (1840-1841). Cycas. Commentarii Phytographici: 110-130. (Luchtmans: Leiden)

Miquel FAW (1842) Monographia Cycadearum. (Rhenum, Utrecht)

Miquel FAW (1843) Genera et species Cycadearum viventium. Linnaea 17: 675-744.

Miquel FAW (1851) Analecta Botanica Indica. (Sulpke: Amsterdam)

Miquel FAW (1852) Cycadis rumphii stirps femina. Linnaea 25: 589-592.

Miquel FAW (1861) Prodromus Systematis Cycadearum. (van der Post: Utrecht and Amsterdam)

Miquel FAW (1868) Cycas. Nouveaux materiaux pour servir a la connaissance des Cycadees. Archives Neerlandaises des Sciences Exactes et Naturelles 3: 226-237.

Mueller F (1876) Descriptive Notes on Papuan Plants, vol.1, part 4, p 71-72. (Government Printer: Melbourne)

Mueller F (1885a) Succinct notes on some plants from New Guinea. Victorian Naturalist 2(2):18-19.

Mueller F (1885b) Descriptive Notes on Papuan Plants, vol 2, part 6, p 15. (Government Printer: Melbourne)

Ochse JJ (1931) Vegetables of the Dutch East Indies. (Archipel Drukkerij: Buitenzorg)

Paijmans K (1976) Vegetation. Pp. 23-105 in Paijmans K (ed.) New Guinea Vegetation. (Elsevier: Amsterdam)

Pant DD (1962) Cycas and the Cycadales. (Central Book Depot: Allahabad, India)

Peekel PG (1984) Flora of the Bismarck Archipelago for naturalists. (EE Henty Division of Botany: Lae)

Pilger R (1926) Cycadaceae. Pp. 44-82 in Engler A (ed.) Die naturlichen pflanzenfamilien, ed. 2, 13.

Regel E (1876a) Cycadearum Generum Specierumque Revisio. (St Petersburg)

Regel E (1876b) Cycadearum Generum Specierumque Revisio. Acta Horti Petropilitani 4: 275-320. 
Ridley HN (1893) On the flora of the eastern coast of the Malay peninsula. Transactions of the Linnaean Society, Botany, series 2, 3: 267-408, as cited in Read \& Solt 1986.

Ridley H (1925) Cycadaceae. Pp. 283-285 in Flora of the Malay Peninsula, vol. 5. (Reeve \& Co. Ltd: London)

Roxburgh W (1832) Flora Indica and descriptions of Indian plants. (Thacker: Calcutta)

Rumphius GE (1741) Herbarium Amboinense 1.(M Uytwerf.: Amsterdam)

Schuster J (1932) Cycadaceae. Pp. 1-168 in Engler A (ed.) Das Pflanzenreich 99 (4, 1).

Smith AC (1979) Flora Vitiensis Nova, vol. 1. (Pacific Tropical Botanic Garden: Hawaii)

Smitinand T (1971) The genus Cycas Linn. (Cycadaceae) in Thailand. Natural History Bulletin of the Siam Society 14 (1-2): 163-175.

Smitinand T (1972) Cycadaceae. Pp. 185-192 in Smitinand T \& Larsen K Flora of Thailand, vol. 2(2). (Applied Scientific Corporation of Thailand: Bangkok)

Stafleu RA \& Cowan RS (1983) Taxonomic Literature (edn 2) 4. Regnum Vegetable 110. (Bohn, Scheltema \& Holkema: Utrecht; W. Junk: The Hague)

Stapf O (1916) Cycas Thouarsii. Kew Bulletin of Miscellaneous Information 1-8.

Stevenson DW (1992) A formal classification of the extant cycads. Brittonia 44: 220-223.

Suvatabandhu K (1961) The living gymnosperms of Thailand. Journal of the National Research Council Thailand 2: 59-62.

Thiselton-Dyer WT (1888) Cycadaceae. Pp. 655-658 in Hooker WJ Flora of British India, vol. 5. (Reeve: London)

Walter K.S. and Gillett HJ (eds) (1998) 1997 IUCN Red List of Threatened Plants. Compiled by the World Conservation Monitoring Centre. (IUCN - The World Conservation Union, Gland, Switzerland and Cambridge, UK)

Wang DY (1996) Taxonomy of Cycas in China. Pp. 33-142 in Wang F-X \&, Liang H-B (eds) Cycads in China. (Guangdong Science and Technology Press: Guangdong, China)

Warburg O (1900) Cycadaceae. Pp. 178-181 in Warburg O (ed.) Monsunia. (Engelmann: Leipzig)

White CT (1923) A contribution to our knowledge of the flora of Papua. Proceedings of the Royal Society of Queensland 1922 34: 5-65.

Zamora PM \& Co L (1986) Guide to Philippine flora and fauna 2: Descriptions of Gymnosperm species. (Ministry of Naural Resources \& University of the Philippines: Quezon City) 